\title{
Clinical significance of P-class pumps in cancer (Review)
}

\author{
SOPHIA C. THEMISTOCLEOUS ${ }^{1 *}$, ANDREAS YIALLOURIS ${ }^{1 *}$, CONSTANTINOS TSIOUTIS $^{1}$, \\ APOSTOLOS ZARAVINOS $^{2,3}$, ELIZABETH O. JOHNSON $^{1}$ and IOANNIS PATRIKIOS ${ }^{1}$ \\ ${ }^{1}$ Department of Medicine, School of Medicine; ${ }^{2}$ Department of Life Sciences, School of Sciences, European University
Cyprus, 2404 Nicosia, Cyprus; ${ }^{3}$ College of Medicine, Member of Qatar University Health, Qatar University, 2713 Doha, Qatar
}

Received January 25, 2021; Accepted Apri 12, 2021

DOI: $10.3892 / \mathrm{ol} .2021 .12919$

\begin{abstract}
P-class pumps are specific ion transporters involved in maintaining intracellular/extracellular ion homeostasis, gene transcription, and cell proliferation and migration in all eukaryotic cells. The present review aimed to evaluate the role of P-type pumps $\left[\mathrm{Na}^{+} / \mathrm{K}^{+}\right.$ATPase (NKA), $\mathrm{H}^{+} / \mathrm{K}^{+}$ATPase (HKA) and $\mathrm{Ca}^{+}$-ATPase] in cancer cells across three fronts, namely structure, function and genetic expression. It has been shown that administration of specific P-class pumps inhibitors can have different effects by: i) Altering pump function; ii) inhibiting cell proliferation; iii) inducing apoptosis; iv) modifying metabolic pathways; and v) induce sensitivity to chemotherapy and lead to antitumor effects. For example, the NKA $\beta 2$ subunit can be downregulated by gemcitabine, resulting in increased apoptosis of cancer cells. The sarcoendoplasmic reticulum calcium ATPase can be inhibited by thapsigargin resulting in decreased prostate tumor volume, whereas the HKA $\alpha$ subunit can be affected by proton pump inhibitors in gastric cancer cell lines, inducing apoptosis. In conclusion, the present review highlighted the central role of P-class pumps and their possible use and role as anticancer cellular targets for novel therapeutic chemical agents.
\end{abstract}

Correspondence to: $\mathrm{Dr}$ Andreas Yiallouris, Department of Medicine (School of Medicine), European University Cyprus, 6 Diogenes Street, Engomi, 2404 Nicosia, Cyprus

E-mail: a.yiallouris@euc.ac.cy

*Contributed equally

Abbreviations: AMOG, adhesion molecule on glia; CaMK, $\mathrm{Ca}^{2+} /$ calmodulin-dependent kinase; $\mathrm{CG}$, cardiac glycoside; ER, endoplasmic reticulum; HKA, hydrogen potassium ATPase; NKA, sodium potassium ATPase; OCCC, ovarian clear cell carcinoma; PDA, pancreatic ductal adenocarcinoma; PPI, proton pump inhibitor; SERCA, sarcoendoplasmic reticulum calcium ATPase; $\mathrm{TAB}$, trametenolic acid B

Key words: NKA, SERCA, HKA, P-type ATPases, cancer, pump subunits

\section{Contents}

1. Introduction

2. Methodology

3. NKA

4. SERCA pump

5. HKA

6. Clinical studies of P-class pump modulators

7. Concluding remarks and future perspectives

\section{Introduction}

The movement of ions across a biological membrane is a crucial physiological process necessary for maintaining cellular homeostasis. Such processes involve different types of membrane proteins which can move ions either down their concentration gradient or against their concentration gradient (1). The latter is considered an active transport mechanism, achieved by dephosphorylating ATP for each pump cycle, a mechanism by which a family of pumps known as P-type ATPases are known to operate with (Fig. 1) $(2,3)$. Cancer treatments currently include different approaches such as surgery, chemotherapy, radiotherapy, immunotherapy or other processes that are characterized to be debilitating and traumatic for a patient with a direct effect on his quality of life (4). Therefore, specific characterized molecular targets could be used for the designing or isolation of novel chemical agents that could potentially be able to affect the tumor cell proliferation through manipulation of those specific molecular targets. P-type ATPases could be considered as such potential targets, as they are proteins regulated by different functional means such as phosphorylation, drug inhibition or activation and/or ion concentration sensitivity $(2,3,5)$.

The P-type ATPases are divided into five families (P1 to P5) that can be further classified to one or more subgroups A, B, C, D $(5,6)$. P-class pumps are proteins, present in all eukaryotic cells, as well as bacteria and are commonly integrated within the lipid bilayer of the cellular membranes $(3,5)$. An essential segment of ATPases is the $\alpha$-subunit that is known to be involved in the enzymatic activity of the pump but also the transport of ions across membranes. The pump expresses variations in structural confirmation depending on the factional stage of the protein found at any time during the transportation or translocation process of the involved ions $(5,7)$. It is 
well characterized that phosphorylation of the $\mathrm{P}$ site results in a conformational change exposing the enzymatic sites (8). Additional domains are also expressed in pumps such as the $\mathrm{R}$ (regulatory) domain involved in auto inhibition of the pump.

Three members of this family have been extensively studied in vitro, in vivo and in clinical studies, the sodium $\left(\mathrm{Na}^{+}\right)$/potassium $\left(\mathrm{K}^{+}\right)$-ATPase (NKA), sarcoendoplasmic reticulum calcium $\left(\mathrm{Ca}^{2+}\right)$ ATPase (SERCA), and the proton $\left(\mathrm{H}^{+}\right) / \mathrm{K}^{+}$ATPase (HKA) (3). NKA, HKA and SERCA are three among many transmembrane proteins that play a significant role in essential cellular functions, e.g., relaxation of muscle tissue or restoration of stomach acidity $(9,10)$. A relationship on a molecular level, between pump behaviour and cancer development/inhibition was also reported. Such an effect could be justified by alterations (mutations) in genetic material, abnormal regulation of pump protein translation or stimulation of some cellular pathways and repression of others (11-16).

It is also known that cancer cells exhibit an acidic environment, extracellular build-up of $\mathrm{H}+$ and production of lactic acid, creating numerous complications (10). These complications include changes in both metastatic and proliferation behaviour but can additionally result in resistance of cancer cells to chemotherapeutic drugs (17). Given the ability of P-type pumps to directly affect ion homeostasis, they are currently being explored as antineoplastic or antitumor targets/biomarkers as able to reverse the changes found in cancer cell environments (10).

This review aims to: (A) provide an understanding of the significance of P-Type ATPases in essential functions of a cell, (B) describe the outcomes when they are inhibited during pathogenesis and specifically cancer (Table I), (C) determine the use of those protein-pumps as potential biological cancer biomarkers and (D) probably propose future advancements.

\section{Methodology}

Evidence regarding P-class pumps was reviewed in in vitro and in vivo studies, as well as in clinical trials, in order to describe their quaternary structure, function, and if they communicate any anticancer effects. A literature search was performed in PubMed to identify relevant articles published from January 2010 until December 2020 and in ClinicalTrials. gov database for any relevant trials. The search was based on the following words and terms: ' $\mathrm{Na}^{+} / \mathrm{K}^{+}$ATPase', 'SERCA', ' $\mathrm{H}^{+} / \mathrm{K}^{+}$ATPase', 'P-type pumps' in association with the term 'cancer' (Fig. 2). The relevant papers found were then searched for discussing the structure, function and the potential involvement of the searched functional entities in cancer treatment. The references of the relevant articles were also accessed and reviewed. Additionally, expression data was collected from the UALCAN http://ualcan.path.uab.edu/ resource to evaluate the degree of gene expression of the pumps in 24 separate cell lines, comparing expression levels in cancer cells to healthy cells (18).

\section{NKA}

NKA structure and function. NKA is crucial for cell function, serving as a signal transducer involved in cell adhesion (14). Ions move against the concentration gradient in order to form and protect the action potential which is vital for many physiological processes in a number of organs. NKA channel is present in the waste management in kidneys, sperm mobility and neuronal action potential production. The regulation of the neuron action potentials is also due to NKA maintaining the concentrations of $\mathrm{Na}^{+}$and $\mathrm{K}^{+}$at constant disequilibrium. When a neuron generates an impulse, a sudden shift is created from resting to active state due to a rapid movement of ions across the membrane.

For every NKA cycle an ATP is hydrolysed followed by three sodium ions binding to the pump to be exported from the cell in exchange of two potassium ions binding to be imported into the cytosol, resulting in a net positive charge extracellularly (19). The NKA transmembrane protein is composed of the $\alpha, \beta$ and FXYD subunits, which are subdivided into various isoforms (Fig. 1). Action potentials are affected by NKA exertions, through polarization/depolarization actions known to generate electrical signals $(8,19,20)$. These subunits express in an heterologous manner and the isoform combinations vary in different tissues (21). The $\alpha$ subunit, as previously described, is the catalytic subunit (7). This structure has a mass of $110-\mathrm{kDa}$ and it is transcribed by 1,000 amino acids and it spans the membrane ten times exhibiting functional domains intracellularly and extracellularly (e.g., A,N,P,R) (8). This subunit is comprised of four isoforms, $\alpha 1-\alpha 4$. The $\alpha 1$ subunit gene ATP1A, of NKA is expressed in most tissues as it plays a key role in signal transduction, cell/cell adhesion and tight junctions (Fig. 3A and B) (22). Its expression is prominent in the ependymal cells of the spinal cord and as well as in neurons of the ventral horn (23). The $\alpha 2$ (ATP1A2) subunit is highly expressed in cardiac T-tubules, skeletal and smooth muscle, lung, astrocytes and adipose tissue (24). The $\alpha 3$ (ATP1A3) subunit is mostly expressed in ventricular myocardial cells, axons and dendrites, while the $\alpha 4$ (ATP1A4) in the testes and epididymis (25-29). The $\beta$ subunit has four separate isoforms (ATP1B1-ATP1B4), all highly glycosylated, situated mostly extracellularly (33-36 kDa) (Fig. 3) (30). The $\beta$ subunits attract $\mathrm{K}^{+}$and incorporate the binding site for cardiac glycosides (31). Expressed in skeletal muscle, heart muscle and human brain is the $\beta 1$ subunit, which is also a constituent of cell-cell adhesion. The $\beta 2$ (32 kDa) subunit is more commonly expressed in glial cells but expressed in myocardial cells and erythrocytes, and is additionally an essential enzyme in cell adhesion in the central nervous system $(32,33)$. The third enzyme is the $\beta 3$ subunit expressed predominately in oligodendrocytes of brain white matter and the optic nerve; it is also detected in testes $(30,34)$. Finally, $\beta 4$ varies from the other $\beta$ isoforms, as it is situated mostly intracellularly $(31,35,36)$ and is encountered in skeletal and cardiac muscle (37).

A third unit of NKA, FXYD, is a significant subunit, sometimes referred to as an accessory unit due to its scarce presence $(16,20)$. This protein is transcribed by the FXYD genes and seven isoforms have been described thus far, FXYD1-FXYD7 (8). FXYD1 (phospholemman) is absent in cardiac tissue resulting in reduced NKA activity, indicating that FXYD1 regulates NKA in this tissue (38). FXYD2 ( $\gamma$ subunit) affects $\mathrm{Na}^{+}$reabsorption in the thick ascending limb in the medulla of the kidney and has a low affinity for $\mathrm{Na}^{+}$(39). FXYD3 (mammary tumor marker) is expressed in breast, lung, small intestine but also stomach, uterus and 
A

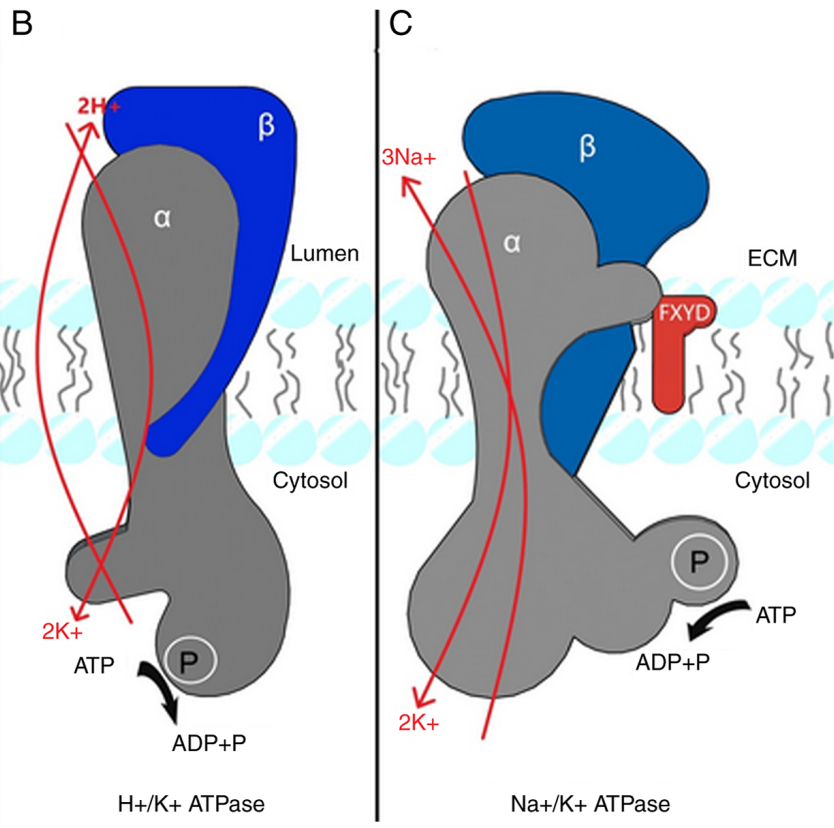

Figure 1. Illustration of the structure and function of P-class pumps created by authors. (A) SERCA pump transports $\mathrm{Ca}^{2+}$ from the cytosol to the lumen. (B) The anti-transportation of $2 \mathrm{H}^{+}$from the cytosol to the lumen and $2 \mathrm{~K}^{+}$from the lumen to the cytosol by HKA to regulate intracellular pH. (C) $\mathrm{NKA}$ is an anti-porter involved in moving $3 \mathrm{Na}^{+}$from the cytosol to the ECM for the charge of $2 \mathrm{~K}^{+}$being transported into the cytosol. All transportations take place in expense of ATP. ECM, extracellular matrix; SR, sarcoendoplasmic reticulum; SERCA, sarcoendoplasmic reticulum calcium ATPase; HKA, proton potassium ATPase; NKA, sodium potassium ATPase.

thymus (40). Additionally, FXYD3 decreases $\mathrm{K}^{+}$affinity, spans the membrane twice instead of once, affects $\beta$ subunit glycosylation and its specificity is low as it is also associated with the $\beta$ subunit of HKA $(41,42)$. The final locus of $\mathrm{Na}^{+}$ reabsorption in the kidneys is from the collecting duct where FXYD4 (channel-inducing factor) is expressed as part of NKA, instead of FXYD2 (43). FXYD4 has a high affinity to $\mathrm{Na}^{+}$therefore ensuring that $\mathrm{Na}^{+}$is reabsorbed into the bloodstream (42). Dysadherin (FXYD5) can double the volume of NKA activity (44). Phosphohippolin, also known as FXYD6, is transcribed in the cerebellum and the posterior lobe of the brain (lobules VI-IX) and is involved in brain neuronal excitability (45). It is additionally expressed in kidney, liver, lung and testis (45). Finally, FXYD7 affects NKA excitability in glial cells and neurons of the brain, by regulating $\mathrm{K}^{+}$movement $(41,46)$. The combination in which the different isoforms of FXYD co-exist with the various isoforms of $\alpha$ and $\beta$, depends on the tissue in question (47).

NKA significance in cancer. The role of NKA in cancer has been supported by a growing number of studies, including in vivo, in vitro and genetic studies that have evaluated either the differential expression of NKA subunits, or the effects of different NKA modulators in malignancy.

Transcription and/or translation of the ion pump protein may either be increased or decreased as a response to the environmental settings created by cancerous cells. The gene expression of each NKA subunit in twenty-four different cancer types was compared to their expression in healthy tissue (Fig. 3A and B) (18). This data is constructive on two fronts: i) It denotes novel biomarkers; ii) It recognises potential treatment targets based on cancer geography. Expression of ATP1A1 in cancerous esophageal cells is significantly greater than in healthy esophageal cells and the same was found true for the expression of this subunit in cervical squamous carcinoma, thymoma, paraganlgioma etc. When evaluating the expression of ATP1A1 in glioblastoma multiforme was found decreased compared to healthy cells. Ideally, these characteristic patterns in protein subunit expression can be manipulated for diagnostic purposes. For example, FXYD3 demonstrates overexpression in gastric adenocarcinomas, prostate carcinoma, pancreatic cancer and in breast tumors as opposed to their healthy counterparts (48). Inhibiting FXYD3 expression can result in down-regulation of cancer cell proliferation, without affecting the invasion rate or cellular apoptosis (49).

As previously reported mutations on specific genes can affect the expression and hence transcription of the NKA subunit, such as ATP1B2 deletions in breast cancer or the deletion of ATPA1A and ATP1B1 in epithelial-mesenchymal transition which can result in cancer and fibrosis $(14,50)$. This was also true for the $\alpha 3 \beta 1$ subunit (isozyme) that was found to be abundant in colon cancer cells that metastasised to the liver, but absent in healthy liver tissue.

Expression is not the only factor affected in cancer cells. Intracellular localization of subunits has been recorded as well, where ATP1A1 is expressed near the peri-nuclear site in cancer environments, but in healthy tissue it it positioned on the basolateral side of cells instead (51). In normal cells, such as in the lung and colon, ATP1A3 is present close to the cytoplasmic membrane, in contrast to its peri-nuclear location in cancer cells of both tissue types. These modifications in intracellular localisation of the $\alpha 1$ and $\alpha 3$ can possibly serve as biomarkers and/or as possible treatment targets (52). As an example, the Oleandrin has been shown to express anti-proliferative activity promoting cell death in undifferentiated $\mathrm{CaCo}-2$ cells (52). 
Table I. Listing of clinical effects of P-class pumps in cancer, containing drug name and target, as well as the upregulated/ downregulated pump.

\begin{tabular}{|c|c|c|c|c|c|}
\hline $\begin{array}{l}\text { First author, } \\
\text { year }\end{array}$ & Drug & $\begin{array}{l}\text { Type of } \\
\text { cancer }\end{array}$ & $\begin{array}{l}\text { Pump } \\
\text { outcome } \\
\text { PETD }\end{array}$ & $\begin{array}{l}\text { Cellular } \\
\text { alterations } \\
\text { PETD }\end{array}$ & (Refs.) \\
\hline Yang et al, 2014 & Oleandrin & $\begin{array}{l}\text { Human } \\
\text { colorectal } \\
\text { cancer } \\
\text { (in vitro) }\end{array}$ & $\begin{array}{l}\downarrow \text { NKA } \\
(\alpha 3)\end{array}$ & $\begin{array}{l}\uparrow \mathrm{K}^{+} \text {intracellularly } \\
\downarrow \mathrm{Ca}^{2+} \text { intracellularly }\end{array}$ & (52) \\
\hline $\begin{array}{l}\text { McConkey et al, } \\
2000\end{array}$ & Oleandrin & $\begin{array}{l}\text { Prostate cancer } \\
\text { (in vitro, in vivo) }\end{array}$ & $\downarrow N K A$ & $\begin{array}{l}\uparrow \mathrm{K}^{+} \text {intracellularly } \\
\downarrow \mathrm{Ca}^{2+} \text { intracellularly }\end{array}$ & (133) \\
\hline $\begin{array}{l}\text { Newman et al, } \\
2007\end{array}$ & Oleandrin & $\begin{array}{l}\text { Pancreatic } \\
\text { cancer } \\
\text { (in vitro) }\end{array}$ & $\downarrow N K A$ & $\begin{array}{l}\downarrow \text { phospho Akt } \\
\uparrow \text { phospho ERK } \\
\downarrow G_{2} / \text { M cell }\end{array}$ & (11) \\
\hline $\begin{array}{l}\text { Li et al, } \\
2011\end{array}$ & $\begin{array}{l}\text { pNaktide } \\
\text { (peptide) }\end{array}$ & $\begin{array}{l}\text { Prostate cancer } \\
\text { (in vivo) }\end{array}$ & $\begin{array}{c}\uparrow N K A \\
(\alpha 1)\end{array}$ & $\begin{array}{l}\uparrow \mathrm{K}^{+} \text {intracellularly } \\
\downarrow \mathrm{Ca}^{2+} \text { intracellularly } \\
\downarrow \mathrm{Src}\end{array}$ & (22) \\
\hline $\begin{array}{l}\text { Garcia et al, } \\
2015\end{array}$ & $\begin{array}{l}\text { Perillyl } \\
\text { alcohol }\end{array}$ & $\begin{array}{l}\text { Glioblastoma } \\
\text { (in vitro) }\end{array}$ & $\begin{array}{c}\downarrow \text { NKA } \\
(\alpha 1)\end{array}$ & $\begin{array}{l}\uparrow \mathrm{K}^{+} \text {intracellularly } \\
\downarrow \mathrm{Ca}^{2+} \text { intracellularly } \\
\downarrow \mathrm{JNK}\end{array}$ & (53) \\
\hline $\begin{array}{l}\text { Alevizopoulos et al, } \\
2016\end{array}$ & Istaroxime & $\begin{array}{l}\text { Prostate cancer } \\
\text { (in vitro, in vivo) }\end{array}$ & $\downarrow N K A$ & $\begin{array}{l}\uparrow \mathrm{K}^{+} \text {intracellularly } \\
\downarrow \mathrm{Ca}^{2+} \text { intracellularly } \\
\text { Caspase- } 3 \downarrow \text { c-Myc } \\
\text { expression }\end{array}$ & (128) \\
\hline $\begin{array}{l}\text { Li et al, } \\
2011\end{array}$ & Bufalin (CG) & $\begin{array}{l}\text { Hepatocallular } \\
\text { carcinoma } \\
\text { (in vitro) }\end{array}$ & $\begin{array}{l}\downarrow \text { NKA } \\
(\alpha 3)\end{array}$ & $\begin{array}{l}\uparrow \mathrm{Akt} \\
\downarrow \mathrm{FOXO} 3 \mathrm{a} \uparrow \mathrm{ERK} \\
\uparrow \mathrm{K}^{+} \text {intracellularly } \\
\downarrow \mathrm{Ca}^{2+} \text { intracellularly }\end{array}$ & (134) \\
\hline $\begin{array}{l}\text { Numazawa et al, } \\
1994\end{array}$ & Bufalin (CG) & $\begin{array}{l}\text { Leukaemia } \\
\text { (in vitro) }\end{array}$ & $\begin{array}{l}\downarrow \text { NKA } \\
(\alpha 3)\end{array}$ & $\begin{array}{l}\uparrow \mathrm{K}^{+} \text {intracellularly } \\
\downarrow \mathrm{Ca}^{2+} \text { intracellularly }\end{array}$ & (135) \\
\hline $\begin{array}{l}\text { Sun et al, } \\
2019\end{array}$ & Bufalin $(\mathrm{CG})$ & $\begin{array}{l}\text { Colorectal } \\
\text { cancer } \\
(\text { in vitro })\end{array}$ & $\begin{array}{c}\downarrow \mathrm{NKA} \\
(\alpha 3)\end{array}$ & $\begin{array}{l}\uparrow \mathrm{K}^{+} \text {intracellularly } \\
\downarrow \mathrm{Ca}^{2+} \text { intracellularly } \\
\downarrow N F-\kappa B \downarrow H I F-1 \alpha \\
\downarrow \text { Cell cycle } \mathrm{G}_{2} / \mathrm{M}\end{array}$ & (136) \\
\hline $\begin{array}{l}\text { Yu et al, } \\
2008\end{array}$ & Cinobufagin $(\mathrm{CG})$ & $\begin{array}{l}\text { Prostate cancer } \\
\text { (in vitro) }\end{array}$ & $\downarrow N K A$ & $\begin{array}{l}\uparrow \mathrm{K}^{+} \text {intracellularly } \\
\downarrow \mathrm{Ca}^{2+} \text { intracellularly } \\
\uparrow \mathrm{Caspase}-3 \\
\text { Cytochrome c } \\
\text { release }\end{array}$ & (137) \\
\hline $\begin{array}{l}\text { Ihenetu et al, } \\
2007\end{array}$ & Digoxin (CG) & $\begin{array}{l}\text { Leukemia } \\
\text { (in vitro) }\end{array}$ & $\downarrow N K A$ & $\begin{array}{l}\uparrow \mathrm{K}^{+} \text {intracellularly } \\
\downarrow \mathrm{Ca}^{2+} \text { intracellularly } \\
\uparrow \mathrm{FasL}\end{array}$ & (12) \\
\hline $\begin{array}{l}\text { Prassas et al, } \\
2011\end{array}$ & Digitoxin (CG) & $\begin{array}{l}\text { Pancreatic cancer } \\
\text { (in vitro) }\end{array}$ & $\downarrow N K A$ & $\begin{array}{l}\uparrow \mathrm{Src} \uparrow \mathrm{MAPK} \\
\text { signalling } \\
\uparrow \mathrm{K}^{+} \text {intracellularly } \\
\downarrow \mathrm{Ca}^{2+} \text { intracellularly }\end{array}$ & $(55)$ \\
\hline $\begin{array}{l}\text { Hsu et al, } \\
2016\end{array}$ & Digoxin (CG) & $\begin{array}{l}\text { Ovarian clear } \\
\text { cell carcinoma } \\
\text { (in vitro, in vivo) }\end{array}$ & $\downarrow N K A$ & $\begin{array}{l}\downarrow \mathrm{FXYD} 2 \\
\uparrow \mathrm{K}^{+} \text {intracellularly } \\
\downarrow \mathrm{Ca}^{2+} \text { intracellularly }\end{array}$ & $(62)$ \\
\hline $\begin{array}{l}\text { Kang et al, } \\
2016\end{array}$ & $\begin{array}{l}\text { Latonoside C } \\
\text { (CG) }\end{array}$ & $\begin{array}{l}\text { Colorectal cancer } \\
\text { (in vitro) }\end{array}$ & $\downarrow N K A$ & $\begin{array}{l}\uparrow \mathrm{K}^{+} \text {intracellularly } \\
\downarrow \mathrm{Ca}^{2+} \text { intracellularly } \\
\text { Repair mitochondrial } \\
\text { membrane } \\
\text { potential }\end{array}$ & (138) \\
\hline
\end{tabular}


Table I. Continued.

\begin{tabular}{|c|c|c|c|c|c|}
\hline $\begin{array}{l}\text { First author, } \\
\text { year }\end{array}$ & Drug & $\begin{array}{l}\text { Type of } \\
\text { cancer }\end{array}$ & $\begin{array}{l}\text { Pump } \\
\text { outcome } \\
\text { PETD }\end{array}$ & $\begin{array}{l}\text { Cellular } \\
\text { alterations } \\
\text { PETD }\end{array}$ & (Refs.) \\
\hline $\begin{array}{l}\text { Liu et al, } \\
2013\end{array}$ & Ouabain (CG) & $\begin{array}{l}\text { Lung cancer } \\
\text { (in vitro) }\end{array}$ & $\downarrow N K A$ & $\begin{array}{l}\uparrow \mathrm{K}^{+} \text {intracellularly } \\
\downarrow \mathrm{Ca}^{2+} \text { intracellularly }\end{array}$ & $(56)$ \\
\hline $\begin{array}{l}\text { Huang et al, } \\
2004\end{array}$ & Ouabain (CG) & $\begin{array}{l}\text { Prostate cancer } \\
\text { (in vitro) }\end{array}$ & $\begin{array}{l}\downarrow \text { NKA } \\
(\alpha)\end{array}$ & $\begin{array}{l}\uparrow \mathrm{K}^{+} \text {intracellularly } \\
\downarrow \mathrm{Ca}^{2+} \text { intracellularly } \\
\text { Restore } \\
\text { mitochondrial } \\
\text { membrane } \\
\text { potential }\end{array}$ & (139) \\
\hline $\begin{array}{l}\text { Ono et al, } \\
2016\end{array}$ & Ouabain (CG) & $\begin{array}{l}\text { Brain } \\
\text { glioblastoma } \\
\text { (in vivo) }\end{array}$ & $\begin{array}{l}\downarrow \text { NKA } \\
(\alpha)\end{array}$ & $\begin{array}{l}\uparrow \mathrm{K}^{+} \text {intracellularly } \\
\downarrow \mathrm{Ca}^{2+} \text { intracellularly }\end{array}$ & (140) \\
\hline $\begin{array}{l}\text { Li et al, } \\
2019\end{array}$ & Digoxin (CG) & $\begin{array}{l}\text { Glioblastoma } \\
\text { (in vitro, in vivo) }\end{array}$ & $\begin{array}{l}\downarrow \text { NKA } \\
(\beta 2)\end{array}$ & $\begin{array}{l}\uparrow \mathrm{K}^{+} \text {intracellularly } \\
\downarrow \mathrm{Ca}^{2+} \text { intracellularly } \\
\text { Cell cycle arrest } \\
\text { at } \mathrm{G}_{2} / \mathrm{M} \text { phase }\end{array}$ & (59) \\
\hline $\begin{array}{l}\text { Rocha et al, } \\
2016\end{array}$ & $\begin{array}{l}\text { 21-benzylidene } \\
\text { digoxin }(\mathrm{CG})\end{array}$ & $\begin{array}{l}\text { Cervical cancer } \\
\text { and colon }\end{array}$ & $\begin{array}{l}\downarrow N K A(\alpha 1) \\
\text { carcinoma } \\
\text { (in vitro) }\end{array}$ & $\begin{array}{l}\text { DNA damage } \\
\uparrow p 21 \downarrow \text { Cyclin A, } \\
\text { Bcl-2 and Bcl-XL }\end{array}$ & (141) \\
\hline $\begin{array}{l}\text { Denmeade and } \\
\text { Isaacs, } 2015\end{array}$ & Thapsigargin & $\begin{array}{l}\text { Prostate cancer } \\
\text { (in vitro, in vivo) }\end{array}$ & $\downarrow$ SERCA & $\begin{array}{l}\downarrow \mathrm{Ca}^{2+} \text { intracellularly } \\
\text { Cytochrome c } \\
\text { release }\end{array}$ & $(142)$ \\
\hline $\begin{array}{l}\text { Mahalingam et al, } \\
2016\end{array}$ & Mipsagargin & $\begin{array}{l}\text { Hepatocellular } \\
\text { carcinoma } \\
\text { (phase i) }\end{array}$ & $\downarrow$ SERCA & $\downarrow \mathrm{Ca}^{2+}$ intracellularly & (81) \\
\hline $\begin{array}{l}\text { Fan et al, } \\
2014\end{array}$ & $\begin{array}{l}\text { Curcumin } \\
\text { Analogue } \\
\text { (F36) }\end{array}$ & $\begin{array}{l}\text { Colorectal } \\
\text { carcinoma } \\
\text { (in vitro) }\end{array}$ & $\downarrow$ SERCA & $\downarrow \mathrm{Ca}^{2+}$ intracellularly & (143) \\
\hline $\begin{array}{l}\text { Denmeade } \text { et al, } \\
2003\end{array}$ & $\begin{array}{l}\text { PSA- } \\
\text { Thapsigargin } \\
\text { prodrug }\end{array}$ & $\begin{array}{l}\text { Metastatic } \\
\text { prostate cancer } \\
(\text { in vitro, } \text { in vivo) }\end{array}$ & $\downarrow$ SERCA & $\downarrow \mathrm{Ca}^{2+}$ intracellularly & (83) \\
\hline $\begin{array}{l}\text { Jia et al, } \\
2016\end{array}$ & Artemisin & $\begin{array}{l}\text { Gallbladder } \\
\text { cancer } \\
\text { (in vitro, in vivo) }\end{array}$ & $\downarrow$ SERCA & $\begin{array}{l}\downarrow \text { ERK } \downarrow \text { CDK } \\
\downarrow \text { Cyclin D1 } \\
\downarrow \mathrm{Ca}^{2+} \text { intracellularly }\end{array}$ & (144) \\
\hline $\begin{array}{l}\text { Riganti et al, } \\
2009\end{array}$ & Artemisin & $\begin{array}{l}\text { Colon cancer } \\
\text { (in vitro) }\end{array}$ & $\downarrow$ SERCA & $\begin{array}{l}\downarrow \mathrm{Ca}^{2+} \text { intracellularly } \\
\downarrow \text { doxorubicin } \\
\text { intracellularly } \\
\uparrow \mathrm{P} \text {-glycoprotein }\end{array}$ & $(86)$ \\
\hline $\begin{array}{l}\text { Riganti et al, } \\
2009\end{array}$ & Parthenolide & $\begin{array}{l}\text { Colon cancer } \\
\text { (in vitro) }\end{array}$ & $\downarrow$ SERCA & $\begin{array}{l}\downarrow \mathrm{Ca}^{2+} \text { intracellularly } \\
\downarrow \text { doxorubicin } \\
\text { intracellularly } \\
\uparrow \mathrm{P} \text {-glycoprotein }\end{array}$ & $(86)$ \\
\hline $\begin{array}{l}\text { De Ford et al, } \\
2016\end{array}$ & $\begin{array}{l}\text { Clerodanee } \\
\text { ditepene } \\
\text { casearin J. }\end{array}$ & $\begin{array}{l}\text { T-cell acute } \\
\text { lymphoblastic } \\
\text { leukemia } \\
\text { (in vitro) }\end{array}$ & $\downarrow$ SERCA & $\begin{array}{l}\downarrow \mathrm{Ca}^{2+} \text { intracellularly } \\
\downarrow \text { Oxidative stress } \\
\uparrow \text { Notch1 }\end{array}$ & (87) \\
\hline $\begin{array}{l}\text { Madreiter- } \\
\text { Sokolowski et al, } \\
2016\end{array}$ & $\begin{array}{l}\text { Resveratrol, } \\
\text { Piceatannol } \\
\text { and oligomycin A }\end{array}$ & $\begin{array}{l}\text { Cervical } \\
\text { adenocarcinoma } \\
\text { (in vitro) }\end{array}$ & $\downarrow$ SERCA & $\begin{array}{l}\downarrow \mathrm{Ca}^{2+} \text { intracellularly } \\
\text { Reverse Loss of } \\
\text { mitochondrial } \\
\text { membrane potential }\end{array}$ & (131) \\
\hline
\end{tabular}


Table I. Continued.

\begin{tabular}{|c|c|c|c|c|c|}
\hline $\begin{array}{l}\text { First author, } \\
\text { year }\end{array}$ & Drug & $\begin{array}{l}\text { Type of } \\
\text { cancer }\end{array}$ & $\begin{array}{l}\text { Pump } \\
\text { outcome } \\
\text { PETD }\end{array}$ & $\begin{array}{l}\text { Cellular } \\
\text { alterations } \\
\text { PETD }\end{array}$ & (Refs.) \\
\hline $\begin{array}{l}\text { Wong et al, } \\
2013\end{array}$ & Saikosaponin-d & $\begin{array}{l}\text { Cervical } \\
\text { cancer and } \\
\text { breast cancer }\end{array}$ & $\downarrow$ SERCA & $\begin{array}{l}\downarrow \mathrm{Ca}^{2+} \text { intracellularly } \\
\uparrow \mathrm{CaMKK} \beta \text {-AMP, } \\
\text { (AMPK), (mTOR) } \\
\text { signaling cascade } \\
\uparrow U n f o l d e d \text { protein } \\
\text { responses }\end{array}$ & (13) \\
\hline $\begin{array}{l}\text { Jakab et al, } \\
2014\end{array}$ & Sch 28080 & $\begin{array}{l}\text { Leukemia } \\
\text { (in vitro) }\end{array}$ & $\begin{array}{c}\downarrow \text { HKA } \\
(\alpha 1)\end{array}$ & $\uparrow \mathrm{H}^{+}$intracellularly & $(100)$ \\
\hline Yeo, 2004 & Pantoprazole & $\begin{array}{l}\text { Gastric cancer } \\
\text { (in vitro, in vivo) }\end{array}$ & $\downarrow$ HKA $(\alpha)$ & $\uparrow \mathrm{H}^{+}$intracellularly & $(108)$ \\
\hline $\begin{array}{l}\text { Zhang et al, } \\
2013\end{array}$ & $\begin{array}{l}\text { Trametenolic } \\
\text { acid B }\end{array}$ & $\begin{array}{l}\text { Gastric cancer } \\
\text { (in vitro, in vivo) }\end{array}$ & $\downarrow \mathrm{HKA}$ & $\uparrow \mathrm{H}^{+}$intracellularly & (107) \\
\hline Gu et al, 2014 & Rabeprazole & Gastric cancer & $\downarrow$ HKA & $\uparrow \mathrm{H}^{+}$intracellularly & $(10)$ \\
\hline Zhang et al, 2013 & Lansoprazole & Breast cancer & $\downarrow$ HKA & $\uparrow \mathrm{H}^{+}$intracellularly & (107) \\
\hline $\begin{array}{l}\text { Lindner et al, } \\
2014\end{array}$ & Esomeprazole & $\begin{array}{l}\text { Esophageal } \\
\text { cancer }\end{array}$ & $\downarrow \mathrm{HKA}$ & $\uparrow \mathrm{H}^{+}$intracellularly & (109) \\
\hline
\end{tabular}

The arrows indicate downregulated or upregulated expression. CAMKK $\beta$, calcium/calmodulin-dependent protein kinase kinase 2; CDK, cyclin-dependent kinase; FasL, Fas ligand; FOXO3a, Forkhead box O3; HIF-1 $\alpha$, hypoxia-inducible factor-1 $\alpha$; PETD, post-exposure to drug; $\mathrm{CG}$, cardiac glycoside; SERCA, sarcoendoplasmic reticulum calcium ATPase; HKA, $\mathrm{H}^{+} / \mathrm{K}^{+}$ATPase; NKA, $\mathrm{Na}^{+} / \mathrm{K}^{+}$ATPase.

As we have previously discussed the $\alpha 1$ subunit is involved in multiple cell functions including the regulation effect on Src (a protein kinase that promotes cell proliferation and invasion) (22). These findings indicated that $\alpha 1$ expression decreases in prostate cancer and human metastatic prostate cell lines (Fig. 3A and B PRAD) while Src activity increased, favouring cancer progression. An in vivo study illustrated that administration of pNaktide peptide could restore the $\alpha 1$ expression with a consequent inhibition of Src action, that further decreased proliferation, migration and/or invasion (Table I) (22). Opposing evidence by in vivo experiments on glioblastoma cells displayed elevated expression of $\alpha 1$ which suppressed Src activity. However, when Src fails to phosphorylate JNK (protein Kinase) the glioblastoma cells proliferate freely, further supporting the influence of Src on cancer cell death. Administering perillyl alcohol, an NKA inhibitor, $\alpha 1$ is downregulated resulting in JNK phosphorylation and initiating glioblastoma cell death (53). Src was further reported able to affect MAPK and p38 proteins (53).

Cardiac glycosides (CGs) are natural compound commonly used in treating heart failure and cardiac arrhythmias; display anticancer effects by decreasing $\mathrm{K}^{+}$, thus increasing $\mathrm{Na}^{+}$and $\mathrm{Ca}^{2+}$ intracellularly; and modify the behaviour of multiple cellular pathways, such as IL- 8 and $\mathrm{TNF}-\alpha / \mathrm{NF}-\mathrm{Kb}$ that are associated with angiogenesis, metastasis or apoptosis $(54,55)$. Ouabain is a CG known to inhibit NKA. Treatment of A549 cells, a lung cancer cell line, with ouabain demonstrated low expression of both $\mathrm{N}$-cadherin and vimentin, both known as epithelial-mesenchymal transition biomarkers, hence indicating decrease of A549 cell migration (56). It has also been shown that ouabain inhibits migration via an epidermal growth factor pathway that causes cytotoxicity in PC-3 (prostate cancer) cells by creating reactive oxygen species (ROS) or upregulating the prostate apoptosis response (56). CGs and their relationship with cancer are listed in Fig. 3A and B. It is also worth noting that the $\alpha 1$ subunit shows low affinity for ouabain which means that the specific drug is more effective when certain alternative are present $(56,57)$.

In medulloblastoma, kidney carcinoma cells, colorectal cancer and liver metastases, tumorigenesis is favoured by inhibiting $\beta 1$. The $\beta 1$ subunit expression is additionally reported to inhibit tumorigenicity in MSV-MDCK cells and able to regulate the ERK pathway (regulating signalling molecules) activation $(8,57)$. NKA $\beta 1$ also affects cellular growth factors such as TGF- $\beta_{2}$, as ion pump inhibition upregulates TGF- $\beta_{2}$ (a growth factor cytokine), activity. Therefore the relationship between pump and disease are eminent, presenting it as a potential drug treatment target (58).

The expression of $\beta 2$ subunits is greatly upregulated in cancer $(59,60)$. in vitro down-regulation of $\beta 2$ expression results in cell cycle arrest in glioblastoma multiforme (GBM) at the $\mathrm{G} 2 / \mathrm{M}$ phase with increased $\mathrm{Ca}^{2+}$ intracellularly, through the sodium/calcium exchanger, resulting in cell apoptosis (59).

The adhesion molecule on glia ( $\beta 2 / \mathrm{AMOG})$ is a glycoprotein that accompanies the $\beta 2$ subunit. As $\beta 2 / \mathrm{AMOG}$ expression decreases in cancer cells the grade of malignancy increases, adhesion is lost and migration is increased (61). Alternatively, the degree of protein pump expression may be useful for prognosis, 


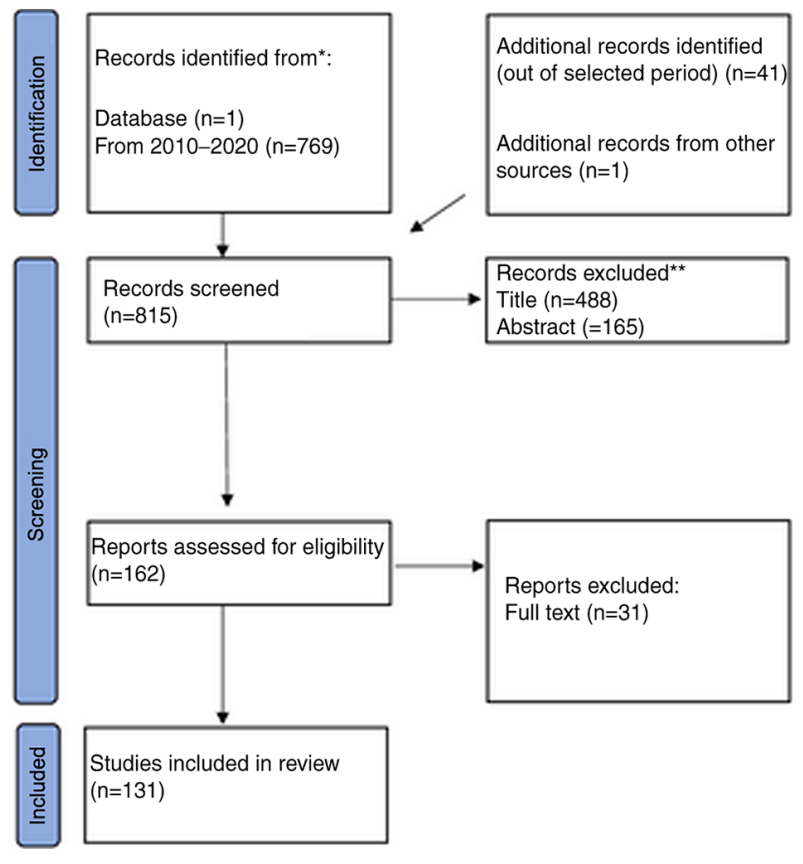

Figure 2. Flowchart of selected papers.

as $\beta 2$ appears to be greatly expressed in primary GBM compared to secondary GBM (60). The opposite is revealed for $\beta 3$, as it is more upregulated in secondary GBM than primary. This pattern may benefit as a prognostic marker (61).

The NKA protein and specifically the FXYD2, is significantly upregulated in ovarian clear cell carcinoma (OCCC) but is scarce to non-existent in surrounding healthy ovarian cells (62). This characteristic increase may be manipulated as a biomarker for OCCC prognostic purposes. Tumor growth is suppressed due to FXYD2 inhibition by digoxin and digitoxin as autophagy-mediated cell death is stimulated (62). Previous studies report a characteristic increase in FXYD3 expression in endometrial cancer, breast tumor, pancreatic and prostate cancer while in lung cancer the expression of the protein was significantly downregulated; possibly suggesting FXYD3 as a biomarker for the aforementioned cancer types $(63,64)$. The same can be supported for FXYD6 in cholangiocarcinoma, while in hepatocellular carcinoma downregulating FXYD6 inhibited NKA activity resulting in a decrease in tumor volume, revealing the protein as a potential treatment target $(65,66)$. In a case of ovarian cancer, FXYD5 involvement in cell adhesion is believed to drive cancer cell migration but may also be a useful mortality predictor (67).

\section{SERCA pump}

SERCA pump structure and function. The SERCA is a $110 \mathrm{kDa}$ power-driven P-type pump that transports two $\mathrm{Ca}^{2+}$ ions from the cytoplasm to the sarco/endoplasmic reticulum lumen per ATP dephosphorylated, balancing free $\mathrm{Ca}^{2+}$ in both eukaryotes and prokaryotes (68). SERCA is also composed of a ten transmembrane $\alpha$ subunit segments (Fig. 1) (69). Three SERCA homologous genes transcribe to three subunits; SERCA1 (gene: ATP2A1), SERCA2 (ATP2A2), and SERCA3(ATP2A3) (70,71). The isoform which will be expressed is determined by alternative splicing of genes, is cell-type dependent and they respond differently to drugs even though they are approximately $75 \%$ homologous (70). SERCA1 consists of two transcripts; 1a is mainly expressed in adult skeletal muscle whereas $1 \mathrm{~b}$ is present in fetal skeletal muscle $(68,72,73)$. SERCA2 also consists of two transcripts. The 2a transcript is found in adult skeletal and cardiac muscle. SERCA $2 b$ is abundant in all adult and fetal cardiac and skeletal muscles. SERCA3 is divided into three isoforms, SERCA3a-3c, all of which are expressed in non-muscle cells $(68,70,73)$.

Signal transduction via intracellularfree $\mathrm{Ca}^{2+}$-concentration $\left[\left(\mathrm{Ca}^{2+}\right)_{\mathrm{i}}\right]$ elevation is one of the fundamental events observed in cell regulation. Systems including muscle cells, neurons, immune system cells as well as plant cells and protozoa utilize $\mathrm{Ca}^{2+}$-signalling.

Free calcium is an important second messenger for the cell. The ER acts as a reservoir and releases the ion into the cytosol upon signaling where it is involved in proliferation, cell death and gene regulation. In neurons, it is the most common intracellular messenger, it is activated by neurotransmitters dopamine and etc. whereas in T cells it is stimulated by the TCR pathway and promotes $\mathrm{T}$ cell immunity.

While $\mathrm{Ca}^{2+}$ concentration is known to be greater extracellularly (cytosol) than intracellularly (lumen), a disordered homeostasis is indicative of pathological conditions, including cancer (68). This action is crucial for a number of cellular processes such as gene transcription, cell proliferation and cell death $(68,74,75)$. Given that SERCA is found in fundamental structures of the cell and is involved in the regulation of cellular metabolism, any pump inhibitor recognised to have anti-tumor effects must be prescribed as a pro-drug to ensure only cancerous cells are affected and leaving healthy cells unharmed (72).

SERCA significance in cancer. The consequence of inhibiting SERCA results in depletion of the $\mathrm{Ca}^{2+}$ concentration in mitochondria that can lead to the collapse of the electrochemical proton gradient, thus triggering numerous signalling pathways resulting in cell death (76). Use of SERCA pump inhibitors in cancer has been verified through in vitro and in vivo studies, with the most commonly used inhibitors being thapsigargin, artemisinin parthenolide, resveratrol and saikosaponin $(13,77)$. In early stages of cancer, a noticeable decrease in SERCA3 is presented by breast cancer, colon cancer and lung adenocarcinoma rendering inhibitors impractical $(71,78)$.

Thapsigargin is a sesquiterpene lactone isolated from Thapsia garganica, which naturally represses ATPase activity, induces endoplasmic reticulum (ER) stress by preventing $\mathrm{Ca}^{2+}$ from leaving the cytosol to enter the ER but also exhibit anti-autophagic effects hence long-lived cytosolic proteins are not broken down (68). While SERCA transmembrane helices are in the E2 conformational state, Thapsigargin can bind to the pump and prevents its return to the initial E1 state capable of binding $\mathrm{Ca}^{2+}$ (more prominently binds to SERCA1b) (68). Therefore, Thapsigargin elevates intracellular free calcium $\left[\left(\mathrm{Ca}^{2+}\right) \mathrm{i}\right]$, through inhibition of the endoplasmic reticulum Ca-ATPase which repossesses calcium from the cytosol $(79,80)$. It has been reported that increase of $\left[\mathrm{Ca}^{2+}\right] \mathrm{i}$ in keratinocytes is associated with differentiation and can be inhibited by $3 \mathrm{nM}$ of thapsigargin. 

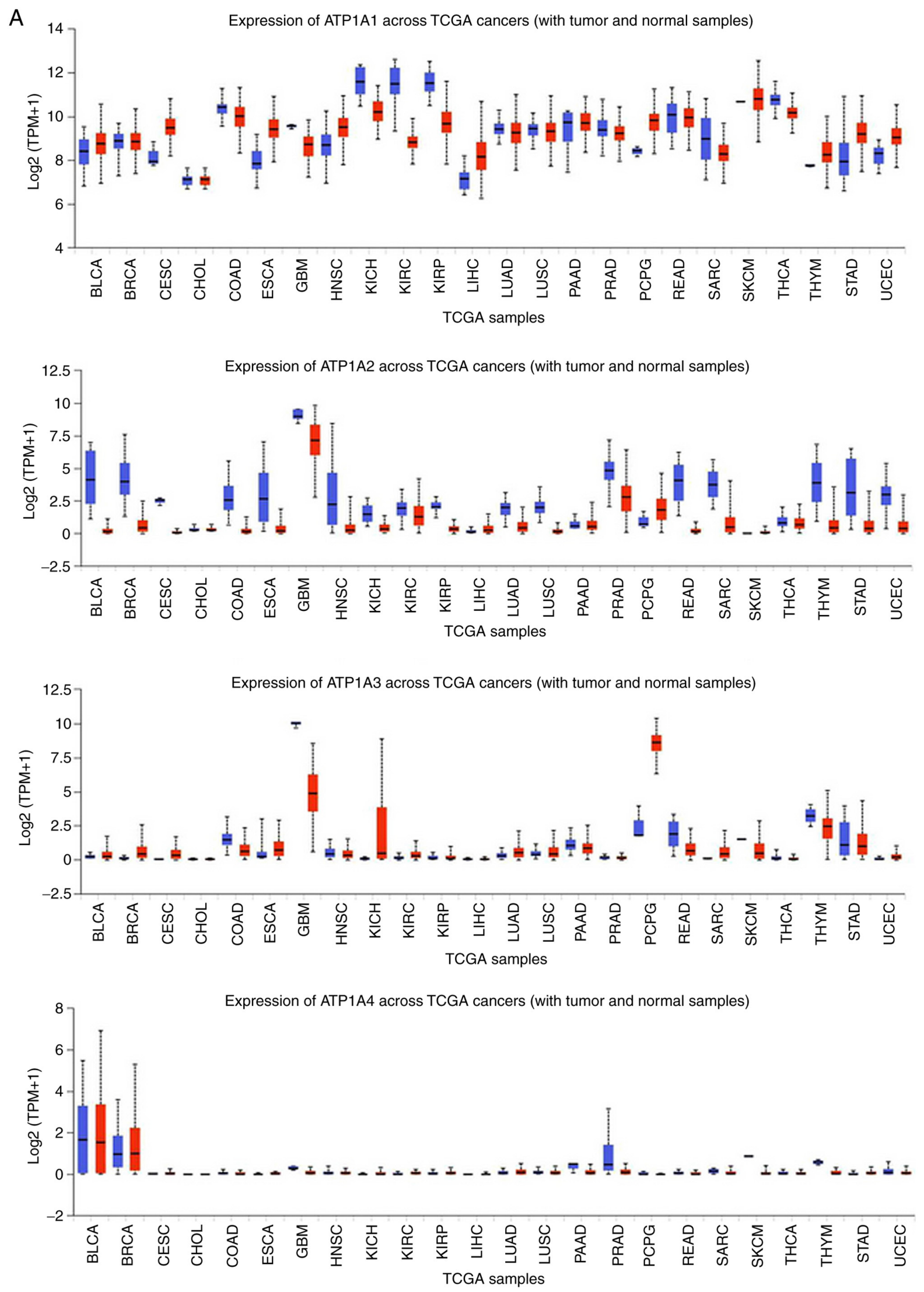

Figure 3. Continued.

Thapsigargin has been reported to promote apoptosis in human hepatoma cells via initiating apoptosis of cells, DNA fragmentation and chromatin condensation $(80,81)$. Similarly, recent clinical studies with mipsagargin, a prodrug of thapsigargin, have supported its use against multiple solid tumors with strong evidence for treatment of hepatocellular carcinoma 

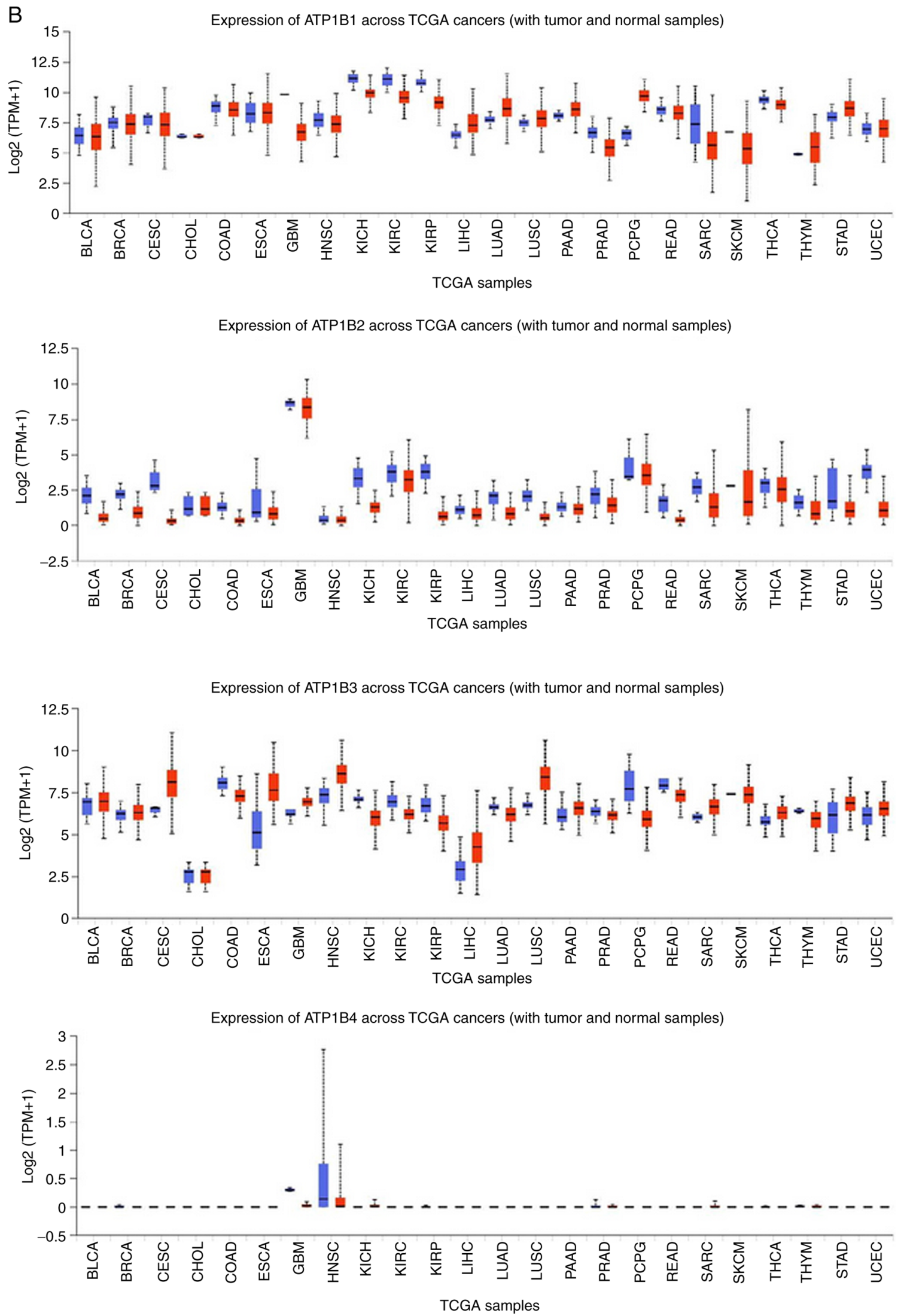

Figure 3. Expression levels of all eight NKA isoforms in 24 types of cancer (red) and their respective healthy tissues (blue). (A) ATP1A1, ATP1A2, ATP1A3 and ATP1A4. (B) ATP1B1, ATP1B2, ATP1B3 and ATP1B4. Data were collected and permitted for publication from the UALCAN resource. TPM, transcripts per million; TCGA, The Cancer Genome Atlas; NKA, Na $/ \mathrm{K}^{+}$ATPase; BLCA, bladder urothelial carcinoma; BRCA, breast invasive carcinoma; CESC, cervical squamous cell carcinoma; $\mathrm{CHOL}$, cholangiocarcinoma; COAD, colon adenocarcinoma; ESCA, esophageal carcinoma; GBM, glioblastoma multiforme; HNSC, head and neck squamous carcinoma; KICH, kidney chromophobe; KIRC, kidney renal clear cell carcinoma; KIRP, kidney renal papillary cell carcinoma; LIHC, liver hepatocellular carcinoma; LUAD, lung adenocarcinoma; LUSC, lung squamous cell carcinoma; PAAD, pancreatic adenocarcinoma; PRAD, prostate adenocarcinoma; PCPG, pheochromocytoma and paragangliosarcoma; READ, rectal adenocarcinoma; SARC, sarcoma; SKCM, skin cutaneous melanoma; THCA, thyroid carcinoma; THYM, thymoma; STAD, stomach adenocarcinoma; UCEC, uterine corpus endometrial carcinoma. 
(Table I) (82). A PSA-Thapsigargin prodrug was administered to nude mice xenograft models diagnosed with prostate cancer and significantly reduced tumor size $(81,82)$. However, a prodrug was used to ensure the effects of thapsigargin on SERCA would not be activated unless bound to prostate tissue, despite its location (83). Thapsigargin also inflicts tumor cell death more sufficiently when administered with a metabolic inhibitor of glucose, in in vivo parental cancer cells $(84,85)$.

SERCA pump disregulation renders chemotherapeutic drugs useless due to the environmental conditions created inside a cell. Artemisinin is a plant-derived drug proven effective in triggering a pro-apoptotic pathway in colorectal adenocarcinoma cells and increases $\mathrm{Ca}^{2+}$ levels intracellularly (86). Doxorubicin is a chemotherapy drug proven effective against HT29, Hep G2, MCF-7 and LoVo cells while expressing cytotoxic effects. Artemisin and parthenolide activate CaMKII which sets off a cascade of events resulting in increased resistance of cancer cells against Doxorubicin, therefore suggesting they should not be administered synergistically. Alternatively, a combination of parthenolide with a product known as clerodane diterpene casearin $\mathrm{J}$, was effective in initiating T-cell acute lymphoblastic leukemia cell apoptosis by inhibiting simultaneously NF- $\mathrm{NB}$ and SERCA respectively (87). Parthenolides ability to inhibit SERCA, hence restoring $\mathrm{Ca}^{2+}$ intracellularly, also assists the successful functioning of 5-fluorouracil (chemotherapy drug) $(86,88)$.

ATP2A2 and ATP2A3 expression is suppressed in human breast cancer and human dermal fibroblast cell lines. Resveratrol, a polyphenol molecule, tested in both these cancer cell lines, is capable of reestablishing ATP2A3 expression therefore decreasing cytosol $\mathrm{Ca}^{2+}$ and consequently decreasing proliferation and triggering apoptosis. Drugs that bind to pumps may be subunit specific, like resveratrol which restores ATP2A3 and not ATP2A2 (89).

As previously mentioned inhibiting pumps can lead to a cascade of cellular alterations. This was also observed when saikosaponin-d, a SERCA inhibitor that promoted autophagy via $\mathrm{Ca}^{2+}$ build-up intracellularly induces ER stress and results in CaMKK $\beta$-AMPK-mTORs signalling activation in cervical and breast cancer cells (13).

Alterations occur in gene expression of all three SERCA subunits when comparing cancer and healthy samples (Fig. 4). Analysing these gene expressions may indicate specific subunits to be used as biomarkers for tissue specific diagnosis of cancer as the previously discussing pumps. For instance, in liver cancer, ATP2A2 is highly expressed compared to healthy cells.

\section{HKA}

HKA structure and function. The HKA is a heterodimer composed of two subunits, $\alpha$ and $\beta$, which are expressed by two separate genes (ATP4A, ATP4B) (90). The ATP4A gene encodes for the gastric $\alpha$ subunit, composed of 10 transmembrane helices and housing the pump inhibitor-binding site intracellularly, known as cysteine 813 . When referring to a separate $\alpha$ subunit located outside the gastric tissue, such as the prostate and skin, it is known as the ATP12A (110 kDA) (91). The ATP4B gene encodes for the $\beta$ subunit ( $35 \mathrm{kDA}$ ) which is highly glycosylated transmembrane protein and protects the enzyme from the stomachs' acidic environment (92).
Apart from the parietal cells of the stomach, the HKA is also found in the distal nephrons of kidneys, prostate, skin and the placenta (93). ATP4A and ATP4B are highly expressed in stomach and esophageal tissue (Fig. 5), which is expected given the action of HKA in maintaining $\mathrm{pH}$ in both organs. However, both HKA subunits are scarce in other tissues, which may explain, at least in part, why studies on this ion pump are limited.

The HKA expresses characteristic structural changes once activated, known as E1 and E2 conformations, leading to the transportation of $\mathrm{H}+$ into the lumen while $\mathrm{K}^{+}$is removed and released into the cytoplasm side of the enzyme (94-96). Therefore, when the protein is open to the cytoplasmic side then it is in the E1 phase, when it is open to the extracellular environment then it is in the E2 phase (92). At an almost neutral $\mathrm{pH}(\sim 6), 2 \mathrm{H}^{+}$and $2 \mathrm{~K}^{+}$are pumped whereas in acidic conditions $(\mathrm{pH} \sim 3), 1 \mathrm{H}^{+}$and $1 \mathrm{~K}^{+}$are transported. For all this to happen, energy from dephosphorylation is required, giving HKA ion pumps the ability to succour the acidic environment in organs such as the stomach (97).

H/K ATPase significance in cancer. The behavior of HKA subunits suggests that ATP4A is more stable when its counterpart, ATP4B is present (98). The absence of ATP4A alone however, resulted in hyperplasia, metaplasia and an imbalance in growth factor in mice in chronic cases suffering from hypergastrinemia and achlorhydria (99). Ion pumps may not always have a direct effect on the pathology of the tissue. Pepsin expresses both inflammatory and carcinogenic effects in the hypopharynx and larynx when active, consequently an acidic environment created by HKA has been proven to activate pepsin freely present in the vicinity or stored in vesicles (98). In the case of rectal cancer, omeprazole improves efficacy of chemotherapy and relieves patients from chemotherapy side effects. As mentioned, these inhibitors bind to the $\alpha$ subunit causing conformational changes which cease ATPase action, hence the pump remains inactive (100). This favourable co-administration of proton pump inhibitor (PPI)-chemotherapeutic drug was noticeable within a human leukemia cell line (HL60 cells), where butyrate was administered inhibiting histone deacetylase (located on ATP12A) favouring apoptosis. However, SCH28080 was required first for inhibiting pump activity and restoring $\mathrm{pH}$ intracellularly (100).

As mentioned above, chemotherapy drugs are often rendered incompetent in eliminating cancer cells due to the greatly acidic environment expressed in tumors (101). Hence, PPIs such as omeprazole, pantoprazole and lansoprazole, serve to restore proton movement across cellular membranes, thus restoring the $\mathrm{pH}$ to levels where chemotherapy drugs can actively express their anticancer effects $(91,102)$. In breast cancer cell lines doxorubicin was significantly more cytotoxic to when administered in combination with PPIs (103). The same was perceived when PPIs were synergistically administered with raloxifene to T47D cells (103), another breast cancer cell line, suppressing cell growth compared to the raloxifene alone. PPI administration was also evaluated in Prostate cancer patients, yet no significant results indicated their effectiveness as a cancer drug (104). HKA (coded by ATP4A, ATP4B and ATP12A) is expressed in pancreatic ducts and is responsible 

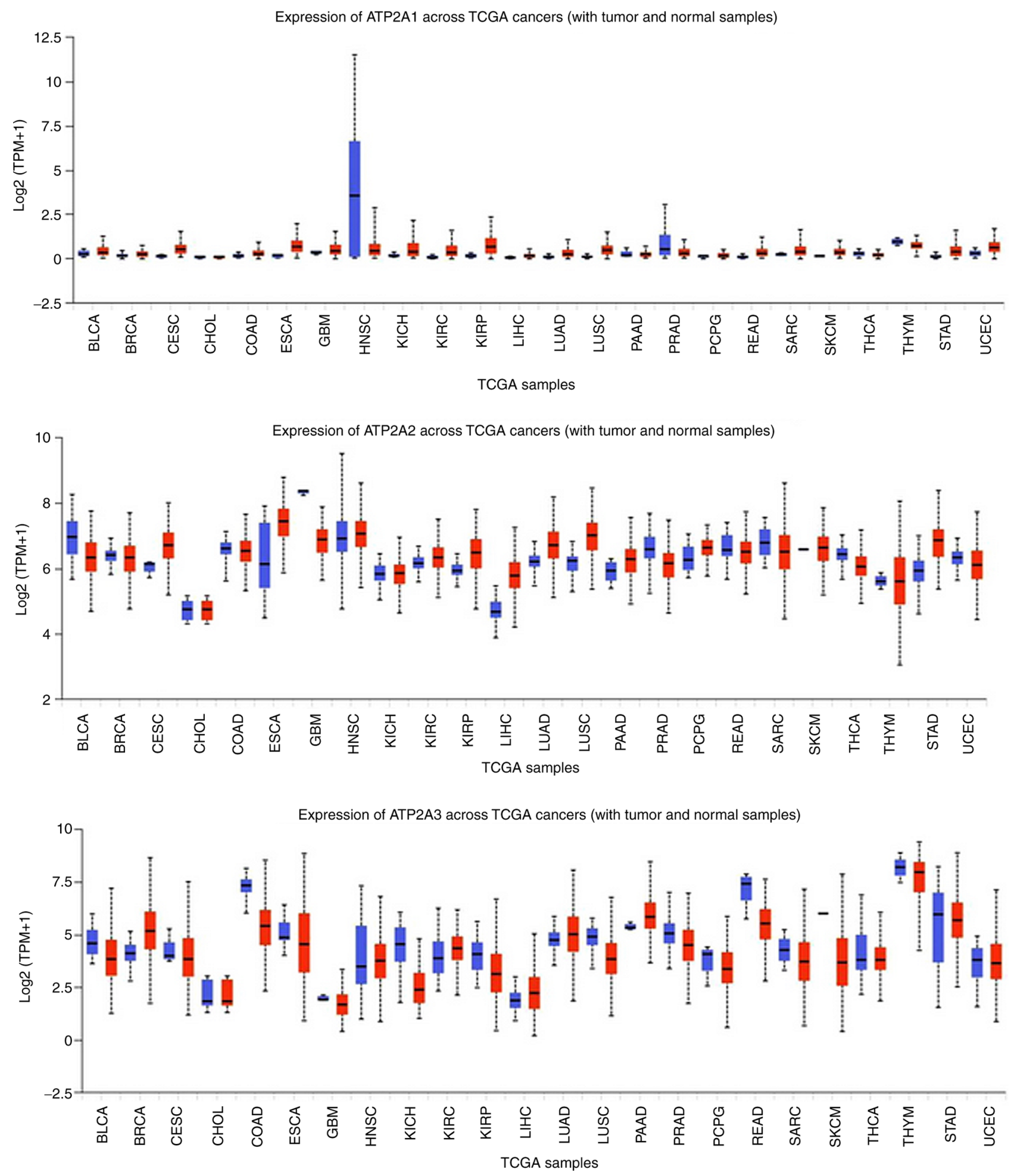

Figure 4. Expression levels of SERCA in 24 cancer tissues compared with in healthy tissues. Data were collected and permitted for publication from the UALCAN resource. TPM, transcripts per million; TCGA, The Cancer Genome Atlas; SERCA, sarcoendoplasmic reticulum calcium ATPase; BLCA, bladder urothelial carcinoma; BRCA, breast invasive carcinoma; CESC, cervical squamous cell carcinoma; CHOL, cholangiocarcinoma; COAD, colon adenocarcinoma; ESCA, esophageal carcinoma; GBM, glioblastoma multiforme; HNSC, head and neck squamous carcinoma; KICH, kidney chromophobe; KIRC, kidney renal clear cell carcinoma; KIRP, kidney renal papillary cell carcinoma; LIHC, liver hepatocellular carcinoma; LUAD, lung adenocarcinoma; LUSC, lung squamous cell carcinoma; PAAD, pancreatic adenocarcinoma; PRAD, prostate adenocarcinoma; PCPG, pheochromocytoma and paragangliosarcoma; READ, rectal adenocarcinoma; SARC, sarcoma; SKCM, skin cutaneous melanoma; THCA, thyroid carcinoma; THYM, thymoma; STAD, stomach adenocarcinoma; UCEC, uterine corpus endometrial carcinoma.

for regulating the secretion of pancreatic fluid but is also expressed in pancreatic cancer cells. Administrating PPIs to pancreatic ductal adenocarcinoma (PDA) and pancreatic stellate cells inhibited proliferation in vitro experiments while in vivo testing on PDA had brought the GO/G1 cell cycle at a halt, hence decreasing both tumor growth and fibrosis (105). 

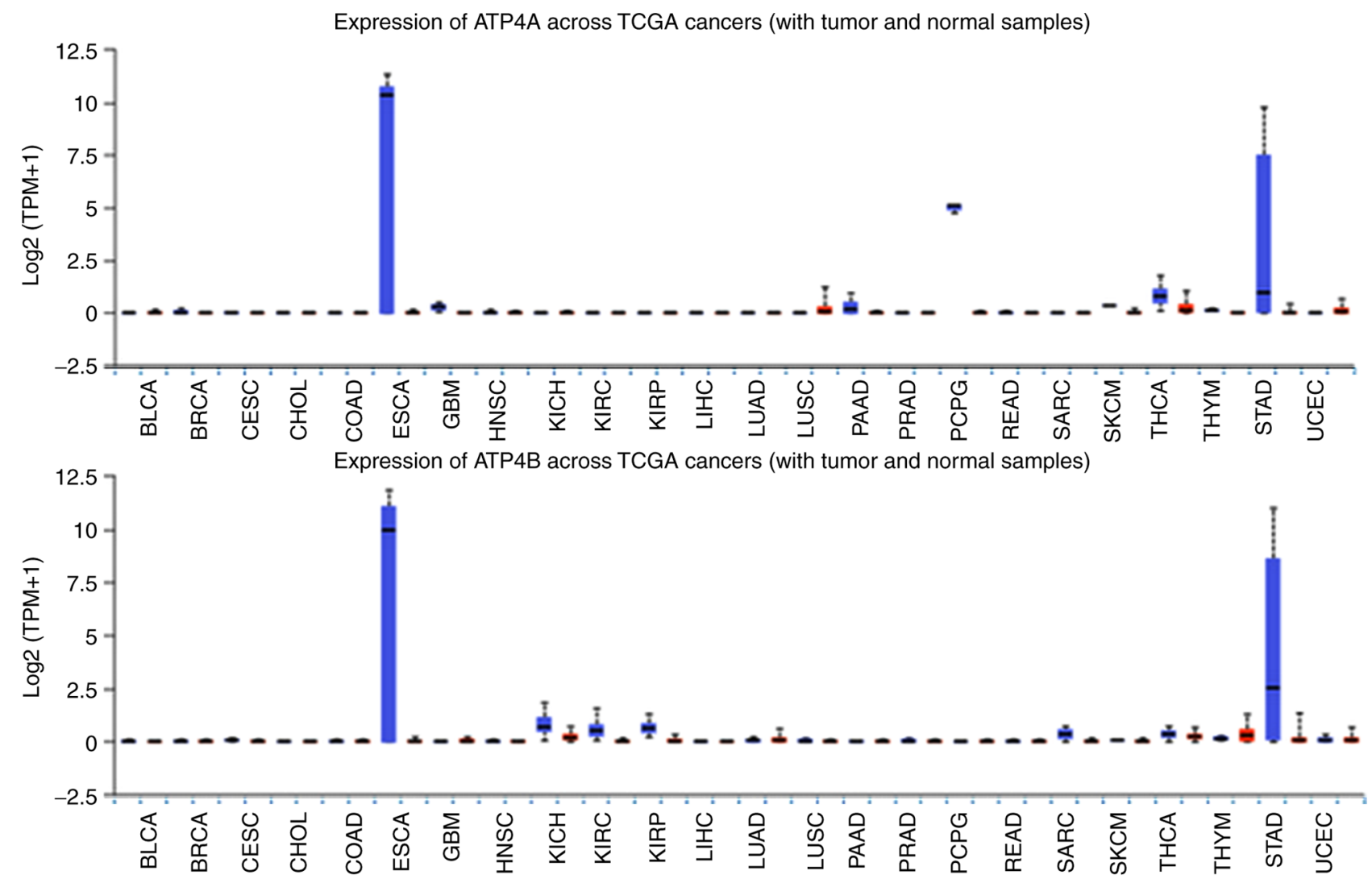

Figure 5. Expression levels of HKA in cancer compared with in healthy tissues across 24 types of cancer. Downregulation of HKA expression was markedly observed in esophageal carcinoma and stomach adenocarcinoma, and was less distinct in thyroid carcinoma. Overall expression in all other tissues appeared to be limited. Data were collected and permitted for publication from the UALCAN resource. TPM, transcripts per million; TCGA, The Cancer Genome Atlas; HKA, $\mathrm{H}^{+} / \mathrm{K}^{+}$ATPase; BLCA, bladder urothelial carcinoma; BRCA, breast invasive carcinoma; CESC, cervical squamous cell carcinoma; CHOL, cholangiocarcinoma; COAD, colon adenocarcinoma; ESCA, esophageal carcinoma; GBM, glioblastoma multiforme; HNSC, head and neck squamous carcinoma; $\mathrm{KICH}$, kidney chromophobe; KIRC, kidney renal clear cell carcinoma; KIRP, kidney renal papillary cell carcinoma; LIHC, liver hepatocellular carcinoma; LUAD, lung adenocarcinoma; LUSC, lung squamous cell carcinoma; PAAD, pancreatic adenocarcinoma; PRAD, prostate adenocarcinoma; PCPG, pheochromocytoma and paragangliosarcoma; READ, rectal adenocarcinoma; SARC, sarcoma; SKCM, skin cutaneous melanoma; THCA, thyroid carcinoma; THYM, thymoma; STAD, stomach adenocarcinoma; UCEC, uterine corpus endometrial carcinoma.

Fig. 5 illustrates that ATP4B is exceedingly reduced in gastric cancer (GC) compared to its high expression in healthy gastric cells and this is also corroborated by the literature (106). This often causes problems in terms of distorting chemotherapeutic drug behaviour. ATP4B can be restored using 5'-aza-2'-deoxycytidine (a DNA methyltransferase inhibitor) or trichostatin A (an histone deacetylase inhibitor), consequently reinstating the $\beta$ subunit further restoring $\mathrm{pH}$ to homeostatic levels, hence creating a suitable environment for docetaxel (chemotherapeutic drug) to function (106).

Trametenolic acid B (TAB) targets HKA in healthy individuals and rectifies $\mathrm{pH}$ in gastric environments reversing gastric ulcers diseases. The inhibitory effects of TAB also promote apoptosis in human gastric carcinoma (HGC-27 cells) and reduce cell viability both in vitro and in vivo (107). Model dose and $\mathrm{pH}$ need to be detailed for the drug to be effective without affecting surrounding healthy cells.

Another PPI is pantoprazole that is activated in acidic environments expressed in tumors, and has been reported capable of inducing apoptosis in MKN-45 cells and RGM-1 cells (108). Evaluation in a GC xenograft indicated suppressed tumor growth and promotion of apoptosis through covalent binding of pantoprazole to the cysteine residues on the $\alpha$ subunit of
HKA, manipulating the extracellular signal-regulated kinases pathway (108). Pantoprazole also proved to reduce chemoresistance to fluorouracil (a chemotherapeutic drug) in both in vitro and in vivo studies in colorectal cancer cells (102). Rabeprazole on the other hand was found to be effective in treating gastric cancer, by preventing ERK $1 / 2$ phosphorylation and simultaneously inhibiting HKA, creating a less acidic environment (10).

Esophageal cancer cells express a sensitivity towards chemotherapeutics when exposed to esomeprazole (ESO) as tumor survival is reduced and metastasis is obstructed (in vitro) (109). ESO proved to alter the expression of miRNAs involved in chemo-resistance as it is a proton pump inhibitor preventing protons from entering the lumen of a cell, resulting in an intracellular basic state $(109,110)$. This action also sensitizes human osteosarcoma cells to cisplatin, another chemotherapeutic drug (110). ESO has also proved effective when administered along with doxorubicin. Doxorubicin-esomeprazole combination was significantly more effective than either drug separately (111). Esomeprazole prevents $\mathrm{H}^{+}$from moving intracellularly, therefore causing a build-up of protons in the tumorigenic cells creating a toxic environment, hence favouring the action of doxorubicin (111). 
Efavirenz, a reverse transcriptase inhibitor, is an antiviral and anti-tumor drug whose action is impaired in acidic conditions. Lansoprazole is a drug that is activated by the acidic environment in cancer cells and its function is to inhibit HKA. Once the HKA is inhibited then the acidic $\mathrm{pH}$ can be overturned to a state where efavirenz can perform. Efavirenz prevents migration of tumor cells and decreases proliferation in human melanoma cells (112). Lansoprazole is also effective in promoting apoptosis and inhibiting proliferation in breast cancer cell lines (MDA-MB-231), while inhibiting tumor growth in vivo (107).

Dexlansoprazole, tenatoprazole, revaprazan and vonoprazan are all PPIs used for treating esophageal reflux disease, with evidence suggesting faster HKA inhibition compared to other PPIs (113-115). However, to the best of our knowledge, they have yet to be evaluated as potential anticancer drugs. Rohitukine, on the other hand, expresses both antiulcer and anticancer properties, but it is uncertain if the anticancer effects are due to HKA pump inhibition (116). Maintaining HKA activity is crucial as additional studies point out that failure to treat disorders such as Helicobacter pylori infection, which renders HKA inactive, may lead to gastric cancer (64).

Compared to NKA and SERCA, HKA subunits expressed in normal and cancer cells have no significant alterations across the 24 cell lines studied using bioinformatic tools, with the exception of gastric and esophageal cells (Fig. 5). This pinpoints the specific subunits to be explored as potential targets for treatment or as biomarkers.

\section{Clinical studies of P-class pump modulators}

Na/K ATPase. Previous studies have shown that NKA expression is altered in various tumors, including drug-resistant tumors, marking it as a potential target by developing NKA modulators $(97,117,118)$. For this reason, different NKA inhibitors, such as perillyl alcohol and cardiac glycosides, are currently being used in a number of clinical trials, to assess their effect on different cancers $(63,119,120)$. Despite their narrow therapeutic window, cardiac glycosides have exhibited acceptable tolerance, so far. In addition to their direct cytotoxic effects and anti-proliferative properties, different NKA modulators can overcome multiple mechanisms of cancer cells that often lead to failure of existing chemotherapeutic agents (117)

In particular, in one study with biochemically-relapsed prostate cancer, digoxin was well-tolerated, but was not of additional benefit compared to that observed in controls reported in previous data (historical controls) (121). A study of patients with BRAF-wild type metastatic melanoma, showed a better response to trametinib when administered with digoxin, compared to studies of trametinib alone (119). In addition, effects of lapatinib on digoxin were assessed in a series of patients with HER2-positive breast cancer, showing that lapatinib significantly increased the absorption of digoxin, thus underscoring the necessity for dose adjustment. No effects on the tumor were reported (120).

SERCA pump. As $\mathrm{Ca}^{2+}$ regulates different cellular functions, including proliferation and differentiation, disruption of $\mathrm{Ca}^{2+}$ pathways may lead to the development of anti-cancer therapies. To this end, altered function of SERCA pumps have shown to contribute to cancer development (70). Among SERCA inhibitors, thapsigargin and its prodrug, mipsagargin, are used in different stages of clinical trials. A study of mipsagargin in patients with advanced solid tumors exhibited acceptable tolerability and safety, whereas cancer stabilization (defined as progression-free survival) was recorded, particularly in patients with hepatocellular carcinoma (81).

$H / K$ ATPase. The clinical usefulness of the HKA is evident in the number of clinical trials that involve PPIs. PPIs can reduce tumor acidity, thus allowing other drugs to reach cancer cells, but also exhibit direct tumor cell toxicity themselves. Additionally, by affecting the acidic environment of the tumor, potentiate the pharmacokinetics of antitumor drugs (102). For this reason, most clinical studies include PPI in combinations for treating malignancies. Combination of high-dose PPIs and aspirin significantly improved composite end-point outcomes in patients with Barrett's esophagus (122). High dose PPI treatment enhanced antitumor effects (translated as time to progression) of chemotherapy in patients with metastatic breast cancer (102). Patients who received PPI during chemotherapy for colorectal cancer, had significantly lower rates of nausea and vomiting compared to patients who did not receive PPI (102). Although pantoprazole did not affect the pharmacokinetics of intravenous doxorubicin in patients with solid tumors, esomeprazole reduced the pharmacokinetic properties of pazopanib in patients with various solid tumors, suggesting decreased absorption of oral pazopanib when the gastric $\mathrm{pH}$ increases $(106,108)$.

\section{Concluding remarks and future perspectives}

The aim of this review was to assess literature sources and determine if there is efficient evidence to support the implication that P-class pumps should be targeted in cancer treatments (Table SI). Overall, ion homeostasis can affect an organ's natural function, diseased or healthy. Research shows that cancer cell environments express ion imbalances (10) and further evidence, presented above, suggest one cause to be the involvement of p-class pumps. Subsequently, the functional roles of NKA, SERCA and HKA (ion pumps) as potential biomarkers but also as probable targets against tumorigenesis and progression were evaluated.

Two of the major setbacks of chemotherapeutic drugs is the hostile environments generated by cancer cells resulting in chemoresistance and toxicity created by the drugs themselves $(110,111,117)$. Numerous reports present evidence of pump inhibitors administered synergistically with chemotherapy drugs overcome the hostile environment and result in inducing cell cycle arrest, decreasing proliferation and angiogenesis in various cancer types and primarily induce apoptosis. Nonetheless, other inhibitors administered in synergy with specific chemotherapeutic drugs have proven to have the unfavorable opposite effect. Some pump inhibitors administered do not express anti-cancerous effects per se but simply layout a more friendly or more hostile environment for the chemotherapeutic drug or cancer cells (100) respectively. Henceforth, further research is necessary to cross-examine which combinations of anticancer drugs to pump inhibitors express a favorable effect on which specific type of cancer cells (103). 
Complication, besides some inconclusive outcomes, have surfaced through the literature where reports imply development of gastric cancer after long-term PPI treatment (123-125). One additional aspect to be considered is that PPIs are commonly metabolised by CYP-mediated isoforms that express drug-drug interactions, meaning other drugs may bind to the same CYP-active sites occupying them or even causing some alterations in the proteins structure. Such actions may render CYP unresponsive when PPIs try to attach, therefore concomitant medication should be considered when administering these drugs (126). Reference to toxicity was scarce throughout the literature, as the majority of reported studies were performed in vitro, however it is a significant feature to consider when selecting drugs for medical administration both short-term and long-term.

This review has also collected data indicating p-type pump expression is altered in tumor cells, affecting various cellular pathways which are involved in cell cycle, apoptosis, angiogenesis and metastasis, activation of MAPK, Caspase 3, ERK phosphorylation, downregulation/inhibition of IL-8, TNF- $\alpha /$ NF- $\kappa B$, f and Bcl-2 (14,53,54,85,127-129). The main finding from the bioinformatics data collected (TCGA database) indicates that the differential expression of NKA, HKA and SERCA pump subunits is not following a specific expression pattern. These subunits expressed in a tissue specific manner with variations of high and low expression in cancer vs normal and vice versa.

Further evaluation of p-class pumps currently administered for other disorders (e.g., HKA in gastric reflux) may assist in determining the exact stage of cellular pathways affected by these pumps hence determining whether they can potentially contribute as novel cancer treatments $(100,130)$. An additional gap identified in the literature is the absence of the exact pump subunits targeted by the drugs as this would help in better understanding and evaluating the behavior of the inhibitors. An example was presented with resveratrol established to specifically target the ATP2A 3 subunit leading to its extensive evaluation and progression into clinical trials (89).

More detailed conclusions could have been drawn with more in-depth analysis of how the biochemical pathways involved are related to both cancer and the p-class pumps. Nevertheless, with this collection it is feasible to identify gaps which remain and directions in which to progress, such as the need for further studies to elucidate the safety and clinical impact of the above findings. The clinical studies section does refer to some additional drugs which are not analysed in detail in the review. There have been other collective reviews on p-class pumps $(77,89,130-132)$. To the best of the authors knowledge no other review has brought together evidence from the literature on the behavior of P-class pumps in-vivo, in-vitro and the clinical environment. The progress made so far towards including p-class pumps as targets against cancer or as architects which utilize chemotherapeutic drugs has been depicted above.

\section{Acknowledgements}

Not applicable.

\section{Funding}

No funding was received.

\section{Availability of data and materials}

Not applicable.

\section{Authors' contributions}

ST and AY conceptualized the study. ST, AY, CT, AZ, EJ and IP collected and interpreted the data. ST, AY and CT drafted the manuscript. All authors revised the manuscript for important intellectual content, and read and approved the final manuscript. Data authentication is not applicable.

\section{Ethics approval and consent to participate}

Not applicable.

\section{Patient consent for publication}

Not applicable.

\section{Competing interests}

The authors declare that they have no competing interests.

\section{References}

1. Lauger P: Dynamics of ion transport systems in membranes. Physiol Rev 67: 1296-1331, 1987.

2. Pedersen PL: Transport ATPases into the year 2008: A brief overview related to types, structures, functions and roles in health and disease. J Bioenerg Biomembr 39: 349-355, 2007.

3. Apell HJ: Structure-function relationship in P-type ATPases-a biophysical approach. Rev Physiol Biochem Pharmacol 150: $1-35,2003$.

4. Litan A and Langhans SA: Cancer as a channelopathy: Ion channels and pumps in tumor development and progression. Front Cell Neurosci 9: 86, 2015.

5. Palmgren MG and Nissen P: P-type ATPases. Annu Rev Biophys 40: 243-266, 2011.

6. Palmgren MG and Axelsen KB: Evolution of P-type ATPases. Biochim Biophys Acta 1365: 37-45, 1998.

7. Kühlbrandt W: Biology, structure and mechanism of P-type ATPases. Nat Rev Mol Cell Biol 5: 282-295, 2004.

8. Clausen MV, Hilbers F and Poulsen H: The structure and function of the Na,K-ATPase isoforms in health and disease. Front Physiol 8: 371, 2017.

9. Toyoshima C, Nakasako M, Nomura H and Ogawa H: Crystal structure of the calcium pump of sarcoplasmic reticulum at $2.6 \mathrm{~A}$ resolution. Nature 405: 647-655, 2000.

10. Gu M, Zhang Y, Zhou X, Ma H, Yao H and Ji F: Rabeprazole exhibits antiproliferative effects on human gastric cancer cell lines. Oncol Lett 8: 1739-1744, 2014.

11. Newman RA, Kondo Y, Yokoyama T, Dixon S, Cartwright C, Chan D, Johansen $M$ and Yang P: Autophagic cell death of human pancreatic tumor cells mediated by Oleandrin, a lipid-soluble cardiac glycoside. Integr Cancer Ther 6: 354-364, 2007.

12. Ihenetu K, Qazzaz HM, Crespo F, Fernandez-Botran R and Valdes R Jr: Digoxin-Like immunoreactive factors induce apoptosis in human acute T-cell lymphoblastic leukemia. Clin Chem 53: 1315-1322, 2007.

13. Wong VK, Li T, Law BY, Ma ED, Yip NC, Michelangeli F, Law CK, Zhang MM, Lam KY, Chan PL and Liu L: Saikosaponin-d, a novel SERCA inhibitor, induces autophagic cell death in apoptosis-defective cells. Cell Death Dis 4: e720, 2013. 
14. Rajasekaran SA, Huynh TP, Wolle DG, Espineda CE, Inge LJ, Skay A, Lassman C, Nicholas SB, Harper JF, Reeves AE, et al: $\mathrm{Na}, \mathrm{K}-\mathrm{ATPase}$ subunits as markers for epithelial-mesenchymal transition in cancer and fibrosis. Mol Cancer Ther 9: 1515-1524, 2010.

15. Dang D and Rao R: Calcium-ATPases: Gene disorders and dysregulation in cancer. Biochim Biophys Acta 1863: 1344-1350, 2016.

16. Arimochi J, Ohashi-Kobayashi A and Maeda M: Interaction of Mat-8 (FXYD-3) with Na+/K+-ATPase in colorectal cancer cells. Biol Pharm Bull 30: 648-654, 2007.

17. De Milito A and Fais S: Tumor acidity, chemoresistance and proton pump inhibitors. Future Oncol 1: 779-786, 2005.

18. Chandrashekar DS, Bashel B, Balasubramanya SAH Creighton CJ, Ponce-Rodriguez I, Chakravarthi BVSK and Varambally S: UALCAN: A portal for facilitating tumor subgroup gene expression and survival analyses. Neoplasia 19: 649-658, 2017.

19. Yiallouris A, Stephanou A and Patrikios I: Anticancer properties of Na+/K+-ATPase: A mini review. Asian J Sci Technol 7 , 2864-2868, 2015.

20. Chakraborti S and Dhalla NS (eds): Regulation of membrane Na+-K+ ATPase. Springer International Publishing, Cham, 2016.

21. Dyla M, Kjærgaard M, Poulsen H and Nissen P: Structure and mechanism of P-Type ATPase ion pumps. Annu Rev Biochem 89: 583-603, 2020

22. Li Z, Zhang Z, Xie JX, Li X, Tian J, Cai T, Cui H, Ding H, Shapiro JI and Xie Z: Na/K-ATPase mimetic pNaKtide peptide inhibits the growth of human cancer cells. J Biol Chem 286 : 32394-32403, 2011.

23. Edwards IJ, Bruce G, Lawrenson C, Howe L, Clapcote SJ, Deuchars SA and Deuchars J: Na+/K+ ATPase $\alpha 1$ and $\alpha 3$ isoforms are differentially expressed in $\alpha$ - and $\mathrm{Y}$-motoneurons. J Neurosci 33: 9913-9919, 2013.

24. Pirahanchi Y, Jessu R and Aeddula NR: Physiology, sodium potassium pump. In: StatPearls. StatPearls Publishing, Treasure Island, FL, 2021

25. Lingrel JB and Kuntzweiler T: $\mathrm{Na}+\mathrm{K}(+)$-ATPase. J Biol Chem 269: 19659-19662, 1994

26. Kaplan JH: Biochemistry of Na,K-ATPase. Annu Rev Biochem 71: 511-535, 2002

27. Pietrini G, Matteoli M, Banker G and Caplan MJ: Isoforms of the Na,K-ATPase are present in both axons and dendrites of hippocampal neurons in culture. Proc Natl Acad Sci USA 89: 8414-8418, 1992.

28. Nawata J, Ohno I, Isoyama S, Suzuki J, Miura S, Ikeda J and Shirato K: Differential expression of alpha 1, alpha 3 and alpha 5 integrin subunits in acute and chronic stages of myocardial infarction in rats. Cardiovasc Res 43: 371-381, 1999.

29. Underhill DA, Canfield VA, Dahl JP, Gros P and Levenson R: The Na,K-ATPase alpha4 gene (Atpla4) encodes a ouabainresistant alpha subunit and is tightly linked to the alpha2 gene (Atp1a2) on mouse chromosome 1. Biochemistry 38: 14746-14751, 1999.

30. Makita N, Bennett PB Jr and George AL Jr: Voltage-gated Na+ channel beta 1 subunit mRNA expressed in adult human skeletal muscle, heart, and brain is encoded by a single gene. J Biol Chem 269: 7571-7578, 1994.

31. Hilbers F, Kopec W, Isaksen TJ, Holm TH, Lykke-Hartmann K, Nissen P, Khandelia $\mathrm{H}$ and Poulsen $\mathrm{H}$ : Tuning of the Na,K-ATPase by the beta subunit. Sci Rep 6: 20442, 2016.

32. Mobasheri A, Trujillo E, Arteaga MF and Martín-Vasallo P: $\mathrm{Na}(+), \mathrm{K}(+)$-ATPase subunit composition in a human chondrocyte cell line; evidence for the presence of $\alpha 1, \alpha 3, \beta 1, \beta 2$ and $\beta 3$ isoforms. Int J Mol Sci 13: 5019-5034, 2012.

33. Sundaram SM, Safina D, Ehrkamp A, Faissner A, Heumann R and Dietzel ID: Differential expression patterns of sodium potassium ATPase alpha and beta subunit isoforms in mouse brain during postnatal development. Neurochem Int 128: 163-174, 2019.

34. Malik N, Canfield VA, Beckers MC, Gros P and Levenson R: Identification of the mammalian Na,K-ATPase 3 subunit. J Biol Chem 271: 22754-22758, 1996.

35. Pestov NB, Zhao H, Basrur V and Modyanov NN: Isolation and characterization of BetaM protein encoded by ATP1B4-a unique member of the Na,K-ATPase $\beta$-subunit gene family. Biochem Biophys Res Commun 412: 543-548, 2011.

36. Mijatovic T, Dufrasne F and Kiss R: $\mathrm{Na}+\mathrm{K}+-\mathrm{ATP} a \mathrm{se}$ and cancer. Pharm Pat Anal 1: 91-106, 2012.
37. Hundal HS, Marette A, Ramlal T, Liu Z and Klip A: Expression of beta subunit isoforms of the $\mathrm{Na}+\mathrm{K}(+)$-ATPase is muscle type-specific. FEBS Lett 328: 253-258, 1993.

38. Jia LG, Donnet C, Bogaev RC, Blatt RJ, McKinney CE, Day KH, Berr SS, Jones LR, Moorman JR, Sweadner KJ and Tucker AL: Hypertrophy, increased ejection fraction, and reduced Na-K-ATPase activity in phospholemman-deficient mice. Am J Physiol Heart Circ Physiol 288: H1982-H1988, 2005.

39. Jones DH, Li TY, Arystarkhova E, Barr KJ, Wetzel RK, Peng J, Markham K, Sweadner KJ, Fong GH and Kidder GM: $\mathrm{Na}, \mathrm{K}-\mathrm{ATP}$ ase from mice lacking the gamma subunit (FXYD2) exhibits altered $\mathrm{Na}+$ affinity and decreased thermal stability. J Biol Chem 280: 19003-19011, 2005.

40. Morrison BW, Moorman JR, Kowdley GC, Kobayashi YM, Jones LR and Leder P: Mat-8, a novel phospholemman-like protein expressed in human breast tumors, induces a chloride conductance in xenopus oocytes. J Biol Chem 270: 2176-2182, 1995.

41. Crambert G, Li C, Swee LK and Geering K: FXYD7, mapping of functional sites involved in endoplasmic reticulum export, association with and regulation of Na,K-ATPase. J Biol Chem 279: 30888-30895, 2004.

42. Geering K: Function of FXYD proteins, regulators of $\mathrm{Na}$, K-ATPase. J Bioenerg Biomembr 37: 387-392, 2005.

43. Mayan H, Farfel Z and Karlish SJD: Renal Mg handling, FXYD2 and the central role of the Na,K-ATPase. Physiol Rep 6: e13843, 2018.

44. Lubarski I, Pihakaski-Maunsbach K, Karlish SJ, Maunsbach AB and Garty $\mathrm{H}$ : Interaction with the $\mathrm{Na}, \mathrm{K}$-ATPase and tissue distribution of FXYD5 (related to ion channel). J Biol Chem 280: 37717-37724, 2005.

45. Kadowaki K, Sugimoto K, Yamaguchi F, Song T, Watanabe Y, Singh K and Tokuda M: Phosphohippolin expression in the rat central nervous system. Brain Res Mol Brain Res 125: 105-112, 2004.

46. Béguin P, Cambert G, Monnet-Tschudi F, Uldry M, Horesberger JD, Garty $\mathrm{H}$ and Geering K: FXYD7 is a brainspecific regulator of $\mathrm{Na}, \mathrm{K}-\mathrm{ATPa} e$ alpha1-beta isozymes. EMBO J 21: 3264-3273, 2002

47. Yamaguchi F, Yamaguchi K, Tai Y, Sugimoto K and Tokuda M: Molecular cloning and characterization of a novel phospholemman-like protein from rat hippocampus. Brain Res Mol Brain Res 86: 189-192, 2001.

48. Zhu ZL, Zhao ZR, Zhang Y, Yang YH, Wang ZM, Cui DS, Wang MW, Kleeff J, Kayed H, Yan BY and Sun XF: Expression and significance of FXYD-3 protein in gastric adenocarcinoma. Dis Markers 28: 63-69, 2010.

49. Grzmil M, Voigt S, Thelen P, Hemmerlein B, Helmke $K$ and Burfeind P: Up-regulated expression of the MAT- 8 gene in prostate cancer and its siRNA-mediated inhibition of expression induces a decrease in proliferation of human prostate carcinoma cells. Int J Oncol 24: 97-105, 2004.

50. Arcangeli A, Crociani O, Lastraioli E, Masi A, Pillozzi S and Becchetti A: Targeting ion channels in cancer: A novel frontier in antineoplastic therapy. Curr Med Chem 16: 66-93, 2009.

51. Baker Bechmann M, Rotoli D, Morales M, Maeso Mdel C, García Mdel P, Ávila J, Mobasheri A and Martín-Vasallo P: $\mathrm{Na}, \mathrm{K}-\mathrm{ATP}$ ase isozymes in colorectal cancer and liver metastases. Front Physiol 7: 9, 2016.

52. Yang P, Cartwright C, Efuet E, Hamilton SR, Wistuba II, Menter D, Addington C, Shureiqi I and Newman RA: Cellular location and expression of $\mathrm{Na}+\mathrm{K}+-\mathrm{ATPase} \alpha$ subunits affect the anti-proliferative activity of oleandrin. Mol Carcinog 53: 253-263, 2014.

53. Garcia DG, de Castro-Faria-Neto HC, da Silva CI, de Souza e Souza KF, Gonçalves-de-Albuquerque CF, Silva AR, de Amorim LM, Freire AS, Santelli RE, Diniz LP, et al: $\mathrm{Na} / \mathrm{K}$-ATPase as a target for anticancer drugs: Studies with perillyl alcohol. Mol Cancer 14: 105, 2015.

54. Slingerland M, Cerella C, Guchelaar HJ, Diederich M and Gelderblom H: Cardiac glycosides in cancer therapy: From preclinical investigations towards clinical trials. Invest New Drugs 31: 1087-1094, 2013

55. Prassas I, Karagiannis GS, Batruch I, Dimitromanolakis A, Datti A and Diamandis EP: Digitoxin-induced cytotoxicity in cancer cells is mediated through distinct kinase and interferon signaling networks. Mol Cancer Ther 10: 2083-2093, 2011.

56. Liu N, Li Y, Su S, Wang N, Wang H and Li J: Inhibition of cell migration by ouabain in the A549 human lung cancer cell line. Oncol Lett 6: 475-479, 2013. 
57. Bogdanov A, Moiseenko F and Dubina M: Abnormal expression of ATP1A1 and ATP1A2 in breast cancer. F1000Res 6 : 10, 2017.

58. Mony S, Lee SJ, Harper JF, Barwe SP and Langhans SA Regulation of Na,K-ATPase $\beta 1$-subunit in TGF- $\beta 2$-mediated epithelial-to-mesenchymal transition in human retinal pigmented epithelial cells. Exp Eye Res 115: 113-122, 2013.

59. Li S, Dai Z, Yang D, Li W, Dai H, Sun B, Liu X, Xie X, Xu R and Zhao X: Targeting $\beta 2$ subunit of $\mathrm{Na}^{+} / \mathrm{K}^{+}$-ATPase induces glioblastoma cell apoptosis through elevation of intracellular $\mathrm{Ca}^{2}$. Am J Cancer Res 9: 1293-1308, 2019.

60. Rotoli D, Cejas MM, Maeso MC, Pérez-Rodríguez ND, Morales M, Ávila J, Mobasheri A and Martín-Vasallo P: The $\mathrm{Na}, \mathrm{K}$-ATPase $\beta$-Subunit isoforms expression in glioblastoma multiforme: Moonlighting roles. Int J Mol Sci 18: 2369, 2017.

61. Sun MZ, Kim JM, Oh MC, Safaee M, Kaur G, Clark AJ, Bloch O, Ivan ME, Kaur R, Oh T, et al: $\mathrm{Na}+\mathrm{K}+-\mathrm{ATPa} e \quad \beta 2$-subunit (AMOG) expression abrogates invasion of glioblastoma-derived brain tumor-initiating cells. Neuro Oncol 15: 1518-1531, 2013.

62. Hsu IL, Chou CY, Wu YY, Wu JE, Liang CH, Tsai YT, Ke JY, Chen YL, Hsu KF and Hong TM: Targeting FXYD2 by cardiac glycosides potently blocks tumor growth in ovarian clear cell carcinoma. Oncotarget 7: 62925-62938, 2016.

63. Li Y, Zhang X, Xu S, Ge J, Liu J, Li L, Fang G, Meng Y, Zhang H and Sun X: Expression and clinical significance of FXYD3 in endometrial cancer. Oncol Lett 8: 517-522, 2014.

64. Xue Y, Lai L, Lian W, Tu X, Zhou J, Dong P, Su D, Wang X Cao X, Chen Y and Wang Q: SOX9/FXYD3/Src Axis is critical for ER ${ }^{+}$breast cancer stem cell function. Mol Cancer Res 17: 238-249, 2019

65. Chen X, Sun M, Hu Y, Zhang H, Wang Z, Zhou N and Yan X: FXYD6 is a new biomarker of cholangiocarcinoma. Oncol Lett 7: 393-398, 2014

66. Gao Q, Chen X, Duan H, Wang Z, Feng J, Yang D, Song L, Zhou N and Yan X: FXYD6: A novel therapeutic target toward hepatocellular carcinoma. Protein Cell 5: 532-543, 2014.

67. Raman P, Purwin T, Pestell R and Tozeren A: FXYD5 is a marker for poor prognosis and a potential driver for metastasis in ovarian carcinomas. Cancer Inform 14: 113-119, 2015.

68. Casemore D and Xing C: SERCA as a target for cancer therapies. Integr Cancer Sci Therap 2: 100-103, 2015.

69. Aubier M and Viires N: Calcium ATPase and respiratory muscle function. Eur Respir J 11: 758-766, 1998.

70. Chemaly ER, Troncone L and Lebeche D: SERCA control of cell death and survival. Cell Calcium 69: 46-61, 2018.

71. Arbabian A, Brouland JP, Apáti Á, Pászty K, Hegedús L, Enyedi Á, Chomienne C and Papp B: Modulation of endoplasmic reticulum calcium pump expression during lung cancer cell differentiation. FEBS J 280: 5408-5418, 2013

72. Colomer-Saucedo JB, Loulousis MM, Copello VA, Krager SL, Tischkau SL and Copello JA: Pharmacological targeting of SERCA in breast cancer. FASEB J 34 (Suppl): S1, 2020.

73. Primeau JO, Armanious GP, Fisher ME and Young HS The SarcoEndoplasmic reticulum calcium ATPase. Subcell Biochem 87: 229-258, 2018

74. Sacchetto R, Bertipaglia I, Giannetti S, Cendron L, Mascarello F, Damiani E, Carafoli E and Zanotti G: Crystal structure of sarcoplasmic reticulum $\mathrm{Ca} 2+-\mathrm{ATPase}$ (SERCA) from bovine muscle. J Struct Biol 178: 38-44, 2012

75. Stewart TA, Yapa KT and Monteith GR: Altered calcium signaling in cancer cells. Biochim Biophys Acta 1848: 2502-2511, 2015.

76. Celsi F, Pizzo P, Brini M, Leo S, Fotino C, Pinton P and Rizzuto R: Mitochondria, calcium and cell death: A deadly triad in neurodegeneration. Biochim Biophys Acta 1787: 335-344, 2009

77. Yousef M, Vlachogiannis IA and Tsiani E: Effects of resveratrol against lung cancer: In vitro and in vivo studies. Nutrients 9 1231, 2017.

78. Papp B, Brouland JP, Arbabian A, Gélébart P, Kovács T, Bobe R, Enouf J, Varin-Blank N and Apáti A: Endoplasmic reticulum calcium pumps and cancer cell differentiation. Biomolecules 2 : 165-186, 2012

79. Sagara Y, Wade JB and Inesi G: A conformational mechanism for formation of a dead-end complex by the sarcoplasmic reticulum ATPase with thapsigargin. J Biol Chem 267: 1286-1292, 1992

80. Jaskulska A, Janecka AE and Gach-Janczak K: Thapsigarginfrom traditional medicine to anticancer drug. Int J Mol Sci 22 4, 2020 .
81. Mahalingam D, Wilding G, Denmeade S, Sarantopoulas J, Cosgrove D, Cetnar J, Azad N, Bruce J, Kurman M, Allgood VE and Carducci M: Mipsagargin, a novel thapsigargin-based PSMA-activated prodrug: Results of a first-in-man phase I clinical trial in patients with refractory, advanced or metastatic solid tumours. Br J Cancer 114: 986-994, 2016.

82. Gu J, Liu H, Fu T and Xu Y: Thapsigargin increases apoptotic cell death in human hepatoma BEL-7404 cells. Cell Res 5: $59-65,1995$

83. Denmeade SR, Jakobsen CM, Janssen S, Khan SR, Garrett ES Lilja H, Christensen SB and Isaacs JT: Prostate-specific antigen-activated thapsigargin prodrug as targeted therapy for prostate cancer. J Natl Cancer Inst 95: 990-1000, 2003.

84. Søhoel H, Jensen AM, Møller JV, Nissen P, Denmeade SR, Isaacs JT, Olsen CE and Christensen SB: Natural products as starting materials for development of second-generation SERCA inhibitors targeted towards prostate cancer cells. Bioorg Med Chem 14: 2810-2815, 2006.

85. Park KC, Kim SW, Jeon JY, Jo AR, Choi HJ, Kim J, Lee HG, Kim Y, Mills GB, Noh SH, et al: Survival of cancer stem-like cells under metabolic stress via CaMK $2 \alpha$-mediated upregulation of sarco/endoplasmic reticulum calcium ATPase expression. Clin Cancer Res 24: 1677-1690, 2018.

86. Riganti C, Doublier S, Viarisio D, Miraglia E, Pescarmona G, Ghigo D and Bosia A: Artemisinin induces doxorubicin resistance in human colon cancer cells via calcium-dependent activation of HIF-1alpha and $\mathrm{P}$-glycoprotein overexpression. $\mathrm{Br}$ J Pharmacol 156: 1054-1066, 2009.

87. De Ford C, Heidersdorf B, Haun F, Murillo R, Friedrich T, Borner $\mathrm{C}$ and Merfort I: The clerodane diterpene casearin J induces apoptosis of T-ALL cells through SERCA inhibition, oxidative stress, and interference with Notch1 signaling. Cell Death Dis 7: e2070, 2016

88. Kim SL, Kim SH, Trang KT, Kim IH, Lee SO, Lee ST, Kim DG, Kang SB and Kim SW: Synergistic antitumor effect of 5-fluorouracil in combination with parthenolide in human colorectal cancer. Cancer Lett 335: 479-486, 2013

89. Izquierdo-Torres E, Rodríguez G, Meneses-Morales I and Zarain-Herzberg A: ATP2A3 gene as an important player for resveratrol anticancer activity in breast cancer cells. Mol Carcinog 56: 1703-1711, 2017

90. Vander Stricht DV, Raussens V, Oberg KA, Ruysschaert JM and Goormaghtigh E: Difference between the E1 and E2 conformations of gastric $\mathrm{H}+/ \mathrm{K}+-\mathrm{ATPa} e$ in a multilamellar lipid film system: Characterization by fluorescence and ATR-FTIR spectroscopy under a continuous buffer flow. Eur J Biochem 268: 2873-2880, 2001

91. Streif D, Iglseder E, Hauser-Kronberger C, Fink KG, Jakab M and Ritter M: Expression of the non-gastric $\mathrm{H}+/ \mathrm{K}+$ ATPase ATP12A in normal and pathological human prostate tissue. Cell Physiol Biochem 28: 1287-1294, 2011

92. Abe K, Tani K, Nishizawa T and Fujiyoshi Y: Inter-subunit interaction of gastric $\mathrm{H}+, \mathrm{K}+-\mathrm{ATPase}$ prevents reverse reaction of the transport cycle. EMBO J 28: 1637-1643, 2009.

93. Sachs G, Shin JM, Vagin O, Lambrecht N, Yakubov I and Munson K: The gastric H,K ATPase as a drug target: Past, present, and future. J Clin Gastroenterol 41 (Suppl 2): S226-S242, 2007

94. Ward RM and Kearns GL: Proton pump inhibitors in pediatrics Mechanism of action, pharmacokinetics, pharmacogenetics, and pharmacodynamics. Paediatr Drugs 15: 119-131, 2013.

95. Sakai H, Fujii T and Takeguchi N: Proton-potassium (H(+)/K(+)) ATPases: Properties and roles in health and diseases. Met Ions Life Sci 16: 459-483, 2016

96. Dubey V, Han M, Kopec W, Solov'yov IA, Abe K and Khandelia $\mathrm{H}$ : $\mathrm{K}^{+}$binding and proton redistribution in the $\mathrm{E} 2 \mathrm{P}$ state of the $\mathrm{H}^{+}, \mathrm{K}^{+}$-ATPase. Sci Rep 8: 12732, 2018.

97. Shin JM, Munson K, Vagin O and Sachs G: The gastric HK-ATPase: Structure, function, and inhibition. Pflugers Arch 457: 609-622, 2009 .

98. McCormick CA, Samuels TL, Battle MA, Frolkis T, Blumin JH, Bock JM, Wells C, Yan K, Altman KW and Johnston N: $\mathrm{H}+\mathrm{K}+\mathrm{ATPase}$ expression in the larynx of laryngopharyngeal reflux and laryngeal cancer patients. Laryngoscope 131: 130-135, 2021

99. Judd LM, Andringa A, Rubio CA, Spicer Z, Shull GE and Miller ML: Gastric achlorhydria in H/K-ATPase-deficient (Atp4a(-/-)) mice causes severe hyperplasia, mucocystic metaplasia and upregulation of growth factors. J Gastroenterol Hepatol 20: 1266-1278, 2005. 
100. Jakab M, Hofer S, Ravasio A, Huber F, Schmidt S, Hitzl W, Geibel JP, Fürst J and Ritter M: The putative role of the non-gastric $\mathrm{H}+/ \mathrm{K}+-\mathrm{ATPa}$ e ATP12A (ATP1AL1) as antiapoptotic ion transporter: Effect of the $\mathrm{H}+/ \mathrm{K}+$ ATPase inhibitor SCH28080 on butyrate-stimulated myelomonocytic HL-60 Cells. Cell Physiol Biochem 34: 1507-1526, 2014.

101. Yan D, Hu Y, Li S and Cheng M: A model of 3D-structure of H+, $\mathrm{K}+$-ATPase catalytic subunit derived by homology modeling. Acta Pharmacol Sin 25: 474-479, 2004

102. Wang X, Liu C, Wang J, Fan Y, Wang Z and Wang Y: Proton pump inhibitors increase the chemosensitivity of patients with advanced colorectal cancer. Oncotarget 8: 58801-58808, 2017.

103. Ihraiz WG, Ahram M and Bardaweel SK: Proton pump inhibitors enhance chemosensitivity, promote apoptosis, and suppress migration of breast cancer cells. Acta Pharm 70: 179-190, 2020

104. Hálfdánarson ÓÖ, Pottegård A, Lund SH, Ogmundsdottir MH, Ogmundsdottir HM and Zoega $\mathrm{H}$ : Use of proton pump inhibitors and mortality among Icelandic patients with prostate cancer. Basic Clin Pharmacol Toxicol 126: 484-491, 2020.

105. Tozzi M, Sørensen CE, Magni L, Christensen NM, Bouazzi R, Buch CM, Stefanini M, Duranti C, Arcangeli A and Novak I: Proton pump inhibitors reduce pancreatic adenocarcinoma progression by selectively targeting $\mathrm{H}^{+}, \mathrm{K}^{+}$-ATPases in pancreatic cancer and stellate cells. Cancers (Basel) 12: 640, 2020.

106. Lin S, Lin B, Wang X, Pan Y, Xu Q, He JS, Gong W, Xing R, $\mathrm{He}$ Y, Guo L, et al: Silencing of ATP4B of ATPase $\mathrm{H}^{+} / \mathrm{K}^{+}$ transporting beta subunit by intragenic epigenetic alteration in human gastric cancer cells. Oncol Res 25: 317-329, 2017.

107. Zhang Q, Huang N, Wang J, Luo H, He H, Ding M, Deng WQ and Zou K: The $\mathrm{H}+/ \mathrm{K}+-\mathrm{ATPase}$ inhibitory activities of trametenolic acid B from trametes lactinea (Berk.) Pat, and its effects on gastric cancer cells. Fitoterapia 89: 210-217, 2013

108. Yeo M, Kim DK, Kim YB, Oh TY, Lee JE, Cho SW, Kim HC and Hahm KB: Selective induction of apoptosis with proton pump inhibitor in gastric cancer cells. Clin Cancer Res 10 8687-8696, 2004.

109. Lindner K, Borchardt C, Schöpp M, Bürgers A, Stock C, Hussey DJ, Haier J and Hummel R: Proton pump inhibitors (PPIs) impact on tumour cell survival, metastatic potential and chemotherapy resistance, and affect expression of resistance-relevant miRNAs in esophageal cancer. J Exp Clin Cancer Res 33: 73 , 2014.

110. Ferrari S, Perut F, Fagioli F, Brach Del Prever A, Meazza C, Parafioriti A, Picci P, Gambarotti M, Avnet S, Baldini N and Fais S: Proton pump inhibitor chemosensitization in human osteosarcoma: From the bench to the patients' bed. J Transl Med 11: 268, 2013.

111. Goh W, Sleptsova-Freidrich I and Petrovic N: Use of proton pump inhibitors as adjunct treatment for triple-negative breas cancers. An introductory study. J Pharm Pharm Sci 17: 439-446, 2014.

112. Lugini L, Sciamanna I, Federici C, Iessi E, Spugnini EP and Fais S: Antitumor effect of combination of the inhibitors of two new oncotargets: Proton pumps and reverse transcriptase. Oncotarget 8: 4147-4155, 2017.

113. Wu DC, Kuo CH, Tsay FW, Hsu WH, Chen A and Hsu PI: A pilot randomized controlled study of dexlansoprazole mr-based triple therapy for Helicobacter pylori infection. Medicine (Baltimore) 95: e2698, 2016

114. Otake K, Sakurai Y, Nishida H, Fukui H, Tagawa Y, Yamasaki H, Karashima M, Otsuka K and Inatomi N: Characteristics of the novel potassium-competitive acid blocker vonoprazan fumarate (TAK-438). Adv Ther 33: 1140-1157, 2016.

115. Inatomi N, Matsukawa J, Sakurai $Y$ and Otake $\mathrm{K}$ : Potassium-competitive acid blockers: Advanced therapeutic option for acid-related diseases. Pharmacol Ther 168: 12-22, 2016.

116. Singh N, Singh P, Shrivastva S, Mishra SK, Lakshmi V, Sharma R and Palit G: Gastroprotective effect of anti-cancer compound rohitukine: Possible role of gastrin antagonism and $\mathrm{H}(+) \mathrm{K}(+)$-ATPase inhibition. Naunyn-Schmiedebergs Arch Pharmacol 385: 277-286, 2012.

117. Mijatovic T, Dufrasne F and Kiss R: Cardiotonic steroids-mediated targeting of the $\mathrm{Na}(+) / \mathrm{K}(+)$-ATPase to combat chemoresistant cancers. Curr Med Chem 19: 627-646, 2012.

118. Bindu PH, Sastry GM, Murty US and Sastry GN: Structural and conformational changes concomitant with the E1-E2 transition in $\mathrm{H}(+) \mathrm{K}(+)$-ATPase: A comparative protein modeling study. Biochem Biophys Res Commun 319: 312-320, 2004.
119. Frankel AE, Eskiocak U, Gill JG, Yuan S, Ramesh V, Froehlich TW, Ahn C and Morrison SJ: Digoxin plus trametinib therapy achieves disease control in BRAF wild-type metastatic melanoma patients. Neoplasia 19: 255-260, 2017.

120. Koch KM, Smith DA, Botbyl J, Arya N, Briley LP, Cartee L, White JH, Beyer J, Dar MM, Chung HC, et al: Effect of lapatinib on oral digoxin absorption in patients. Clin Pharmacol Drug Dev 4: 449-453, 2015.

121. Lin J, Zhan T, Duffy D, Hoffman-Censits J, Kilpatrick D, Trabulsi EJ, Lallas CD, Chervoneva I, Limentani K, Kennedy B, et al: A pilot phase II Study of digoxin in patients with recurrent prostate cancer as evident by a rising PSA. Am J Cancer Ther Pharmacol 2: 21-32, 2014

122. Jankowski JAZ, de Caestecker J, Love SB, Reilly G, Watson P, Sanders S, Ang Y, Morris D, Bhandari P, Brooks C, et al: Esomeprazole and aspirin in Barrett's oesophagus (AspECT): A randomised factorial trial. Lancet 392: 400-408, 2018.

123. Cheung KS and Leung WK: Long-term use of proton-pump inhibitors and risk of gastric cancer: A review of the current evidence. Therap Adv Gastroenterol 12: 175628481983451 , 2019.

124. Hammadi M, Adi M, John R, Khoder GA and Karam SM: Dysregulation of gastric H,K-ATPase by cigarette smoke extract. World J Gastroenterol 15: 4016-4022, 2009.

125. Robertson DJ, Larsson H, Friis S, Pedersen L, Baron JA and Sørensen HT: Proton pump inhibitor use and risk of colorectal cancer: A population-based, case-control study. Gastroenterology 133: 755-760, 2007.

126. Roche VF: The chemically elegant proton pump inhibitors. Am J Pharm Educ 70: 101, 2006.

127. Inge LJ, Rajasekaran SA, Yoshimoto K, Mischel PS, McBride W, Landaw E and Rajasekaran AK: Evidence for a potential tumor suppressor role for the Na,K-ATPase beta1-subunit. Histol Histopathol 23: 459-467, 2008.

128. Alevizopoulos K, Dimas K, Papadopoulou N, Schmidt EM, Tsapara A, Alkahtani S, Honisch S, Prousis KC, Alarifi S, Calogeropoulou $\mathrm{T}$, et al: Functional characterization and anti-cancer action of the clinical phase II cardiac $\mathrm{Na}+\mathrm{K}+$ ATPase inhibitor istaroxime: In vitro and in vivo properties and cross talk with the membrane androgen receptor. Oncotarget 7 : 24415-22428, 2016.

129. Chow DC and Forte JG: Functional significance of the beta-subunit for heterodimeric P-type ATPases. J Exp Biol 198: 1-17, 1995.

130. Peterson JA, Oblad RV, Mecham JC and Kenealey JD Resveratrol inhibits plasma membrane $\mathrm{Ca}^{2+}$-ATPase inducing an increase in cytoplasmic calcium. Biochem Biophys Rep 7: 253-258, 2016.

131. Madreiter-Sokolowski CT, Gottschalk B, Parichatikanond W, Eroglu E, Klec C, Waldeck-Weiermair M, Malli R and Graier WF: Resveratrol specifically kills cancer cells by a devastating increase in the $\mathrm{Ca} 2+$ coupling between the greatly tethered endoplasmic reticulum and mitochondria. Cell Physiol Biochem 39: 1404-1420, 2016.

132. Almasi S and El Hiani Y: Exploring the therapeutic potential of membrane transport proteins: Focus on cancer and chemoresistance. Cancers (Basel) 12: 1624, 2020.

133. McConkey DJ, Lin Y, Nutt LK, Ozel HZ and Newman RA: Cardiac glycosides stimulate $\mathrm{Ca} 2+$ increases and apoptosis in androgen-independent, metastatic human prostate adenocarcinoma cells. Cancer Res 60: 3807-3812, 2000.

134. Li H, Wang P, Gao Y, Zhu X, Liu L, Cohen L, Meng Z and Yang P: Na+/K+-ATPase $\alpha 3$ mediates sensitivity of hepatocellular carcinoma cells to bufalin. Oncol Rep 25: 825-830, 2011.

135. Numazawa S, Shinoki MA, Ito H, Yoshida T and Kuroiwa $Y$ Involvement of $\mathrm{Na}+\mathrm{K}(+)$-ATPase inhibition in $\mathrm{K} 562$ cell differentiation induced by bufalin. J Cell Physiol 160: 113-120, 1994.

136. Sun X, Ng TTH, Sham KWY, Zhang L, Chan MTV, Wu WKK and Cheng CHK: Bufalin, a traditional Chinese medicine compound, prevents tumor formation in two murine models of colorectal cancer. Cancer Prev Res (Phila) 12: 653-666, 2019.

137. Yu CH, Kan SF, Pu HF, Jea Chien E and Wang PS: Apoptotic signaling in bufalin- and cinobufagin-treated androgen-dependent and -independent human prostate cancer cells. Cancer Sci 99: 2467-2476, 2008.

138. Kang MA, Kim MS, Kim W, Um JH, Shin YJ, Song JY and Jeong JH: Lanatoside $\mathrm{C}$ suppressed colorectal cancer cell growth by inducing mitochondrial dysfunction and increased radiation sensitivity by impairing DNA damage repair. Oncotarget 7: 6074-6087, 2016. 
139. Huang YT, Chueh SC, Teng CM and Guh JH: Investigation of ouabain-induced anticancer effect in human androgen-independent prostate cancer PC-3 cells. Biochem Pharmacol 67: 727-733, 2004.

140. Ono Y, Chiba S, Yano H, Nakayama N, Saio M, Tsuruma K, Shimazawa M, Iwama $\mathrm{T}$ and Hara $\mathrm{H}$ : Glycoprotein nonmetastatic melanoma protein $\mathrm{B}(\mathrm{GPNMB})$ promotes the progression of brain glioblastoma via $\mathrm{Na}^{+} / \mathrm{K}^{+}$-ATPase. Biochem Biophys Res Commun 481: 7-12, 2016.

141. Rocha SC, Pessoa MT, Neves LD, Alves SL, Silva LM, Santos HL, Oliveira SM, Taranto AG, Comar M, Gomes IV, et al: 21-Benzylidene digoxin: A proapoptotic cardenolide of cancer cells that up-regulates $\mathrm{Na}, \mathrm{K}-\mathrm{ATP}$ ase and epithelial tight junctions. PLoS One 9: e108776, 2014.

142. Denmeade SR and Isaacs JT: The SERCA pump as a therapeutic target: Making a 'smart bomb' for prostate cancer. Cancer Biol Ther 4: 21-29, 2005.
143. Fan L, Li A, Li W, Cai P, Yang B, Zhang M, Gu Y, Shu Y, Sun Y, Shen Y, et al: Novel role of Sarco/endoplasmic reticulum calcium ATPase 2 in development of colorectal cancer and its regulation by F36, a curcumin analog. Biomed Pharmacother 68: $1141-1148,2014$.

144. Jia J, Qin Y, Zhang L, Guo C, Wang Y, Yue X and Qian J: Artemisinin inhibits gallbladder cancer cell lines through triggering cell cycle arrest and apoptosis. Mol Med Rep 13: 4461-4468, 2016.

This work is licensed under a Creative Commons Attribution-NonCommercial-NoDerivatives 4.0 International (CC BY-NC-ND 4.0) License. 